\title{
Salir con una cámara
}

DOI: http://dx.doi.org/10.18566/comunica.n41.a07

Fecha de recepción: 3 de septiembre de 2019

Fecha de aceptación: 30 de octubre de 2019
Dedico este trabajo a dos amigos y colegas que partieron el año pasado: Ramón H. Londoño y Juan Carlos Berrío. Al igual que yo, encontraron en la fotografía un medio para ser ellos mismos y expresarse. Siempre serán parte de mi historia en la Facultad de Comunicación Social de la UPB. Los llevo en mi corazón.

Salir con una cámara es disponerse a documentar la vida con su infinita gama de matices e interacciones. El tema y la metodología suelen surgir sobre la marcha. Como toda mirada, es subjetivo: cada individuo decide qué fotografiar a partir de su estilo, interés, formación y sentido ético. La cámara solo es la herramienta. El "para qué" y el "cómo" también son algo personal. En mi caso, el aparato (la cámara) también hace las veces de micrófono y microscopio.

Todo depende de la intención. Me explico: la cámara amplía mi voz para que lo que veo tenga más resonancia, para que suene más duro y hasta más alegre (como cuando uno pone un vallenato en el Polo Norte). Por su parte, el microscopio-cámara me aumenta lo pequeño para que lo aprecie con riqueza de detalles y sea yo quien lo asimile primero. Aunque parezca obvio, "lo ampliado se aprecia mejor". Con la cámara indago y cuestiono el mundo que habito y el que visito. Con ella también juego, discuto y me hago reír. La cargo como a mis manos, la uso como a mis ojos y su peso se suma al mío.

Salir con una cámara es estar dispuesta a descubrir realidades, con sus contingencias, vicisitudes, simplezas o complejidades. Fotografiar es observar y detenerme en lo que encuentro relevante, convencida de que nadie distinto a mí puede distinguir "lo relevante" de lo que no lo es. Fotografiar es también un acto de libertad o rebeldía.

Salir con una cámara es enfrentarse a la posibilidad de encontrar algo o no encontrar nada. A veces, las mejores fotografías son las que nunca se tomaron. Al respecto tengo una lista de ejemplos. El más memorable sucedió en la zona rural de Segovia, España. El ambiente era más o menos este: una carretera solitaria en medio de un paisaje tranquilo, con pequeñas colinas, variedad de árboles y aves, casas muy viejas y caídas, establos, vacas, caballos y ausencia de gente. ¡Fascinante! Todo invitaba a la calma, a
Comunicación

número 41

Julio - diciembre

2019 | pp. 83-103

\section{Gloria N.}

\section{Ramírez-Oliveri}

Comunicadora social

periodista de la Universidad

Pontificia Bolivariana,

Medellín. Magíster en

Liberal Arts-Spanish de

California State University

Northridge (CSUN). Docente

en la Universidad Pontificia

Bolivariana, Universidad

Lasallista y Universidad

de Manizales. Tutora de

español e investigadora del

programa de Periodismo

en español de la CSUN.

Representante de la CSUN

en seminarios académicos

realizados en Chaminade

University of Hawaii, Arizona

State University. Reportera

gráfica independiente.

Editora asociada de la

revista www.revistacronopio.

com

gloria.oliveri.881@my.csun. edu 
la contemplación, al disfrute sin alarmas ni "vips"..., a escuchar el silencio. Después de conducir por varios minutos y no encontrar ningún carro en el camino, a poca distancia, en un alto, dos vehículos estaban detenidos en una pequeña glorieta y un agente de policía hablaba con los pasajeros y controlaba "el tráfico". El tráfico de dos carros.

“iQué cosa tan extraña!", pensé. "Algo muy grave tiene que haber sucedido para que por un paraje tan deshabitado como este haya aparecido la policía a decir que hay que devolverse". Por la rapidez de su acto, supuse que los pasajeros de los dos carros de adelante eran habitantes del lugar y estaban acostumbrados a esos "retenes" tan particulares, pues sin el más mínimo reparo simplemente se devolvieron.

La curiosidad y hasta algo de temor me hicieron llegar a la conclusión de que algo muy delicado estaba sucediendo y que aquello no era lo que parecía: el "trancón" causado ya por tres vehículos en uno de los lugares más apacibles que he conocido. El agente de policía lo único que decía era:

- ¡Devolveoss, que no podéiss continuar por aquí!

Algunos temores también caminan con uno y su cámara, pero nunca en ese paisaje bucólico, en el que se debieron inspirar poetas, amantes, juglares y ascetas. Afirmaría que hasta el mismísimo fray Luis de León (poeta español del siglo XVI) tuvo que haberlo conocido para escribir su "Oda de la vida retirada":

¡Qué descansada vida

la del que huye del mundanal ruido,

y sigue la escondida

senda, por donde han ido

los pocos sabios que en el mundo han sido!...

Sin procesar lo dicho por el oficial, " ¡Devolveoss, que no podéiss continuar por aquí!", me preguntaba "¿qué será lo que está sucediendo en este territorio de paz?". Y la preocupación aumentó cuando empecé a sospechar que había caído en una trampa y que estaba en una "cueva de lobos". "iSí, lobos, y no ovejas, es lo que debe haber por aquí!". Afortunadamente, durante el recorrido no vi a ninguna Caperucita Roja que pudiera estar en peligro. Después, otros pensamientos, como titulares de prensa, empezaron a surgir. El pánico era total. Llegué a un veredicto: el planeta está en peligro y ningún lugar es lo que parece. Por todas partes explotan bombas, hay tiroteos. Se pelean guerras. Se matan ballenas. Se asesinan mujeres, niños, indigenas, líderes sociales... Se trafica con armas, drogas y personas. Aumenta el número de indigentes y se reduce el caudal de los ríos y el color verde de los bosques. Se contamina el aire. Se envalentonan 
dictadores. Se compran gobiernos, se trafica con la fe. Se derriban escuelas y se caen edificios. Desaparecen estudiantes. Explotan minas y con ellas sus mineros. Se escucha el llanto de viudas y el grito de huérfanos. Se acaloran los pingüinos y se derriten los polos. Se multiplican las enfermedades y no hay remedio para la ignorancia... Todos los males del mundo aparecieron de repente y se estrujaron en la mente.

Paralizada de miedo, entendí que el oficial estaba cumpliendo con su deber y que era mejor obedecer y continuar con vida (ninguna foto vale más que la vida, recordé). Los personajes de la infancia aparecieron para calmarme y susurrar al oído: "Tranquila, que no panda el cúnico". Recuperé la calma y conjuré el terror.

Salir con una cámara es un modo personal de izar la bandera para tomar posición, para aclarar de qué lado se está. Qué se promueve y qué se rechaza. Fotografiar en periodismo es ver para mostrar a otros. Es revelar sin lineamientos ni puestas en escena. Es congelar el tiempo con la esperanza de atraparlo y hasta transformarlo de algún modo.

Es a partir de este ejercicio constante que salir con una cámara se convierte en otra manera de vivir, de interpretar y de entender el mundo. De eso se trata el trabajo periodístico, documental y de interés humano que he realizado por más de 30 años.

Caminar con la cámara es, en suma, no solo el medio para revelar instantes, en su mayoría cotidianos (con sus circunstancias de tiempo, modo y lugar), sino también la motivación para pensar, escribir, opinar y explorar aspectos de mi realidad y de la que descubro al moverme por el mundo.

Salir con la cámara es aceptar que no todo tiene que ser fotografiado, porque lo más sublime, lo más bello o entrañable puede ser la fotografía que nunca se tomó, como la de Segovia, España, cuando un agente dijo (como ya dije):

- “iDevolveoss, que no podéiss continuar por aquí!”.

Ante aquella orden tan implacable e injustificada, le pregunté:

- ¿Y por qué no podemos continuar?

- ¡Os tenéis que desviar porque viene un pastor con sus ovejas!

Minutos después, y cuando ya no me lo esperaba ni era posible tomar fotos, vi descender al pastor de Segovia con su rebaño de ovejas. Ningún fotógrafo ni pintor podría haber captado toda la majestuosidad de aquella escena. 
Comunicación

número 41

Julio - diciembre

Esa imagen, como otras, es una para nunca olvidar. Allí, en Segovia, había ovejas en lugar de lobos.

Regocijarse con la vida, lo simple y lo sencillo forma parte de mi esencia personal y profesional.

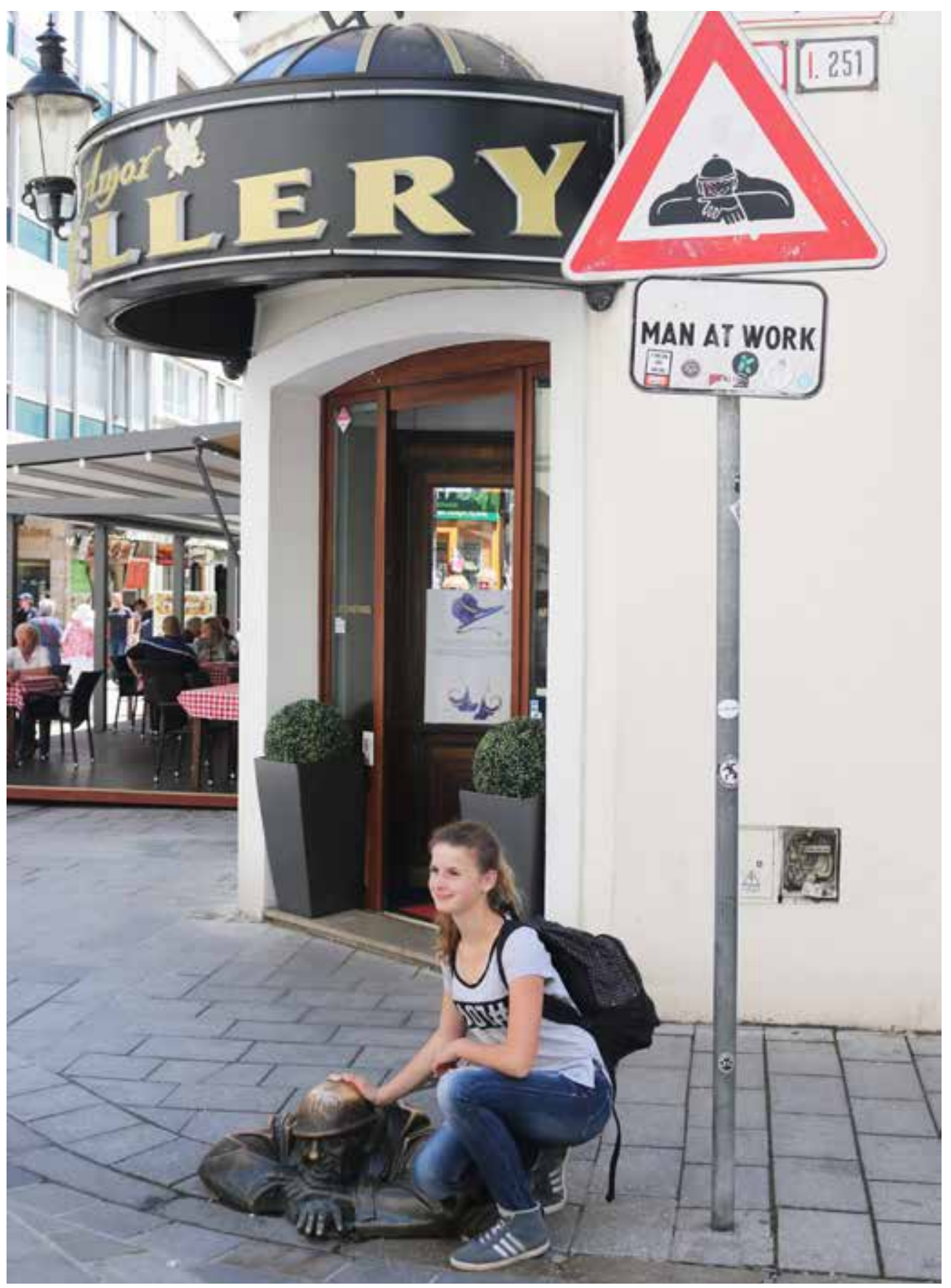

Bratislava (Eslovaquia) 
comunicación

número 41

Julio - diciembre

2019

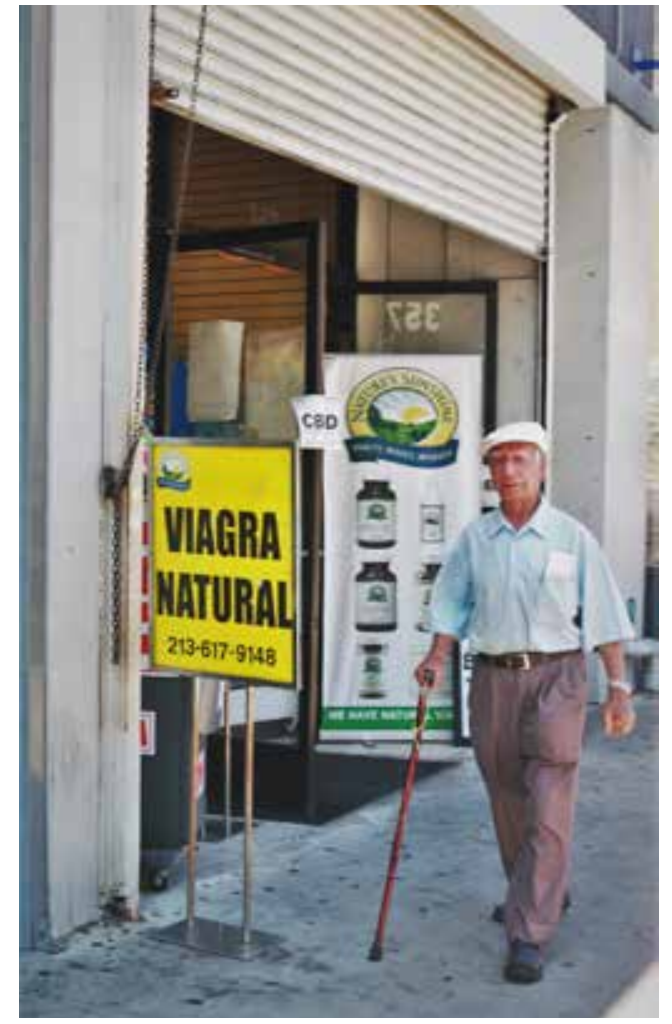

Los Ángeles (Estados Unidos)

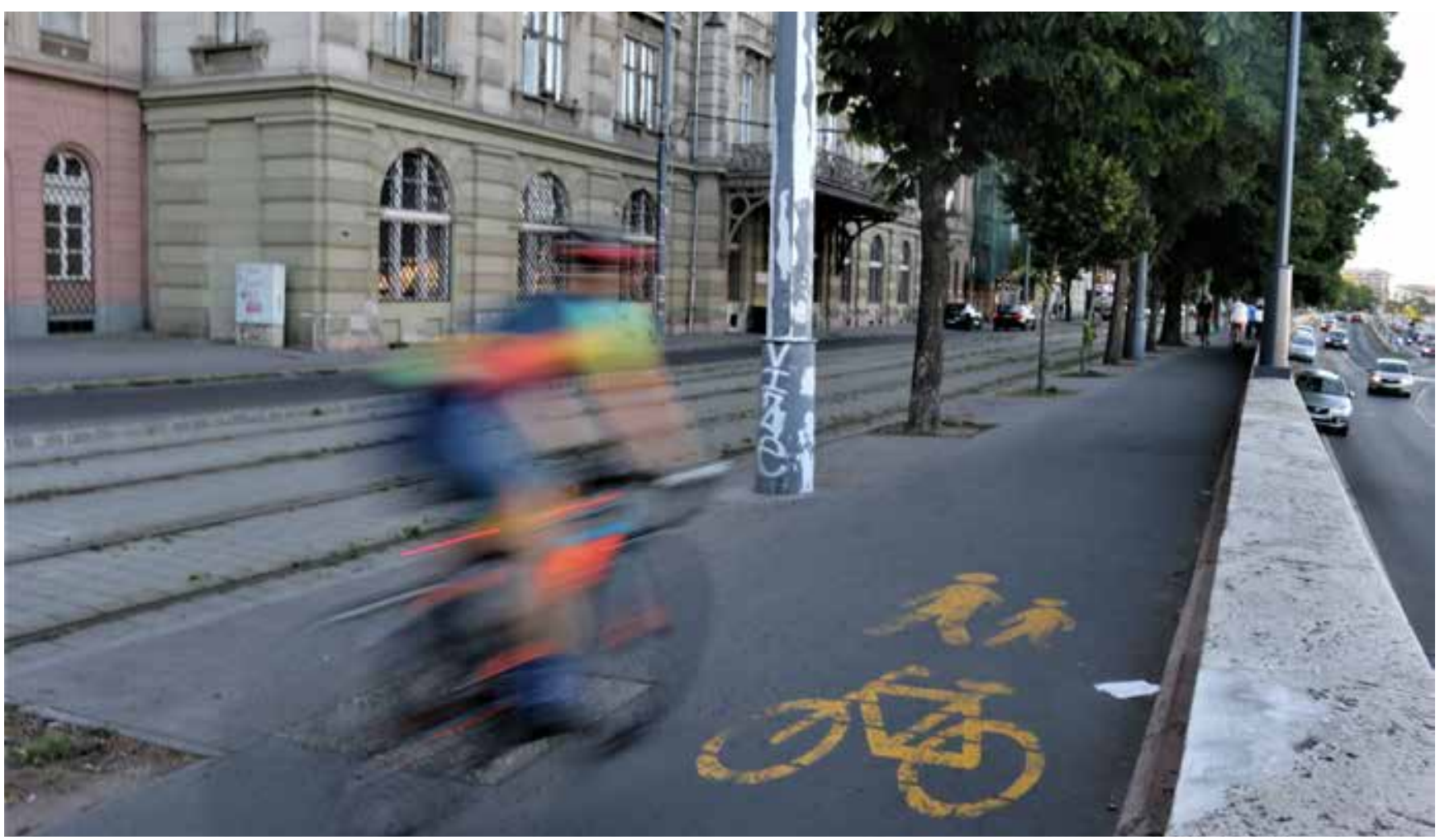




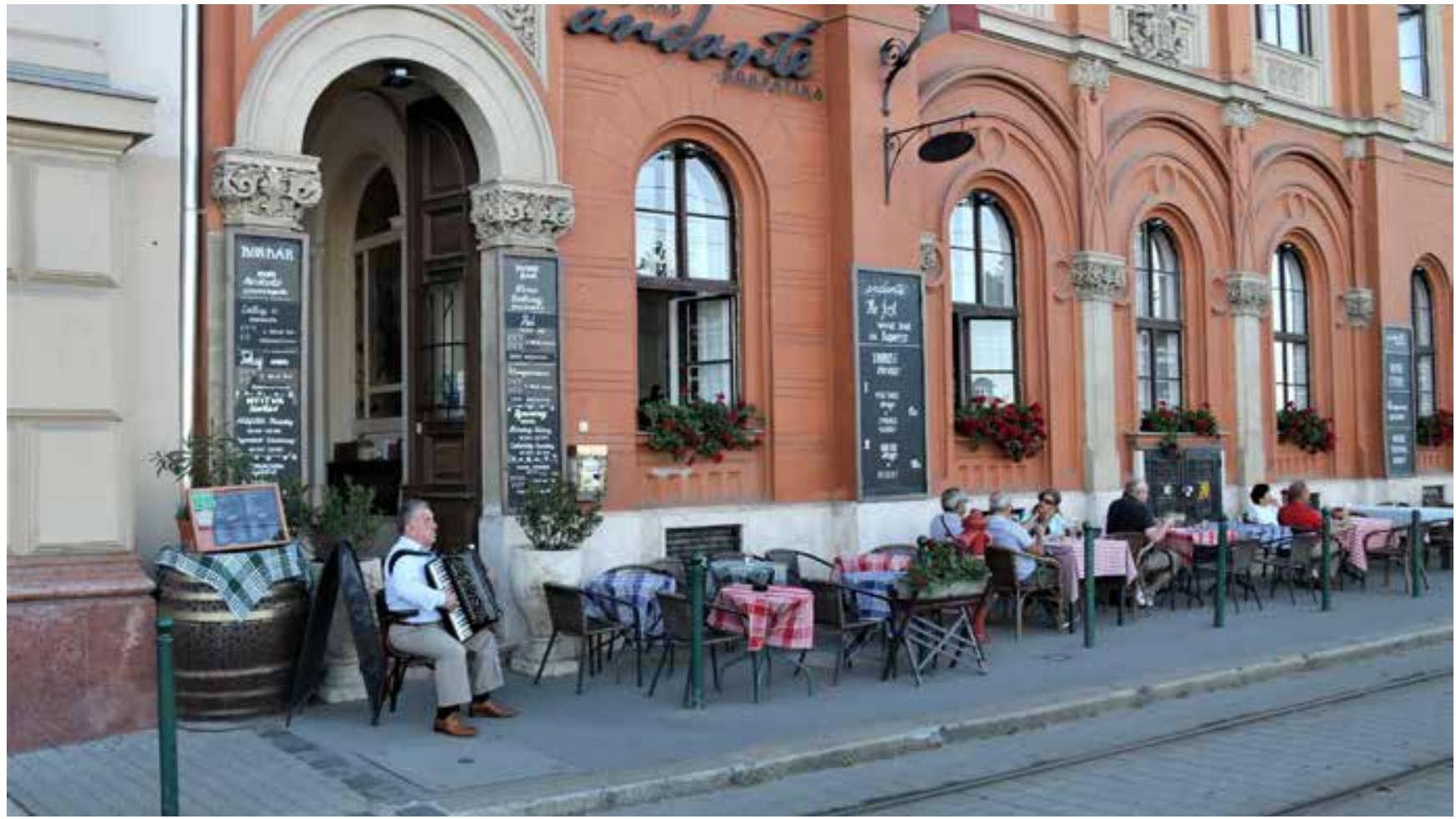

Budapest (Hungría)

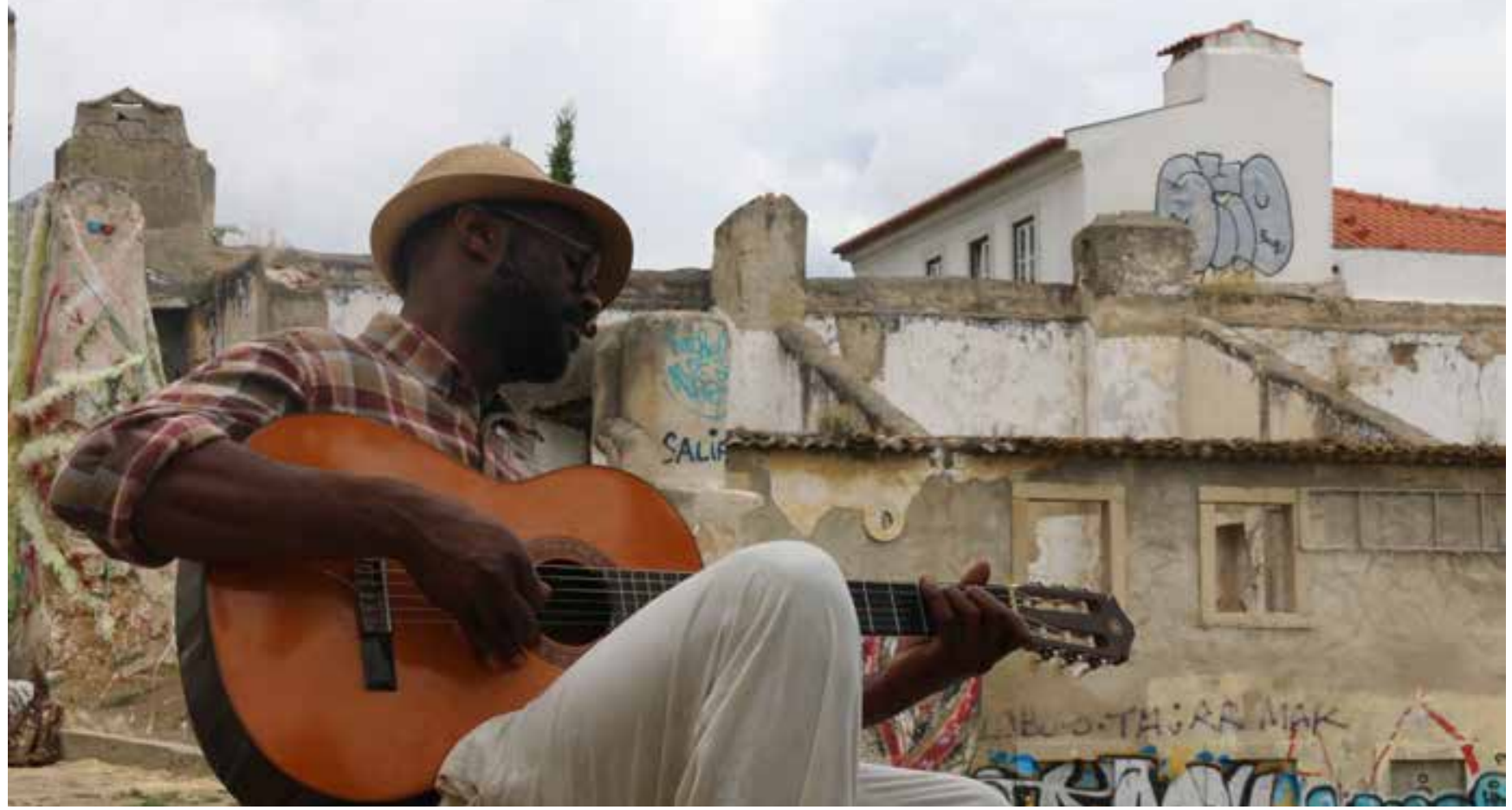



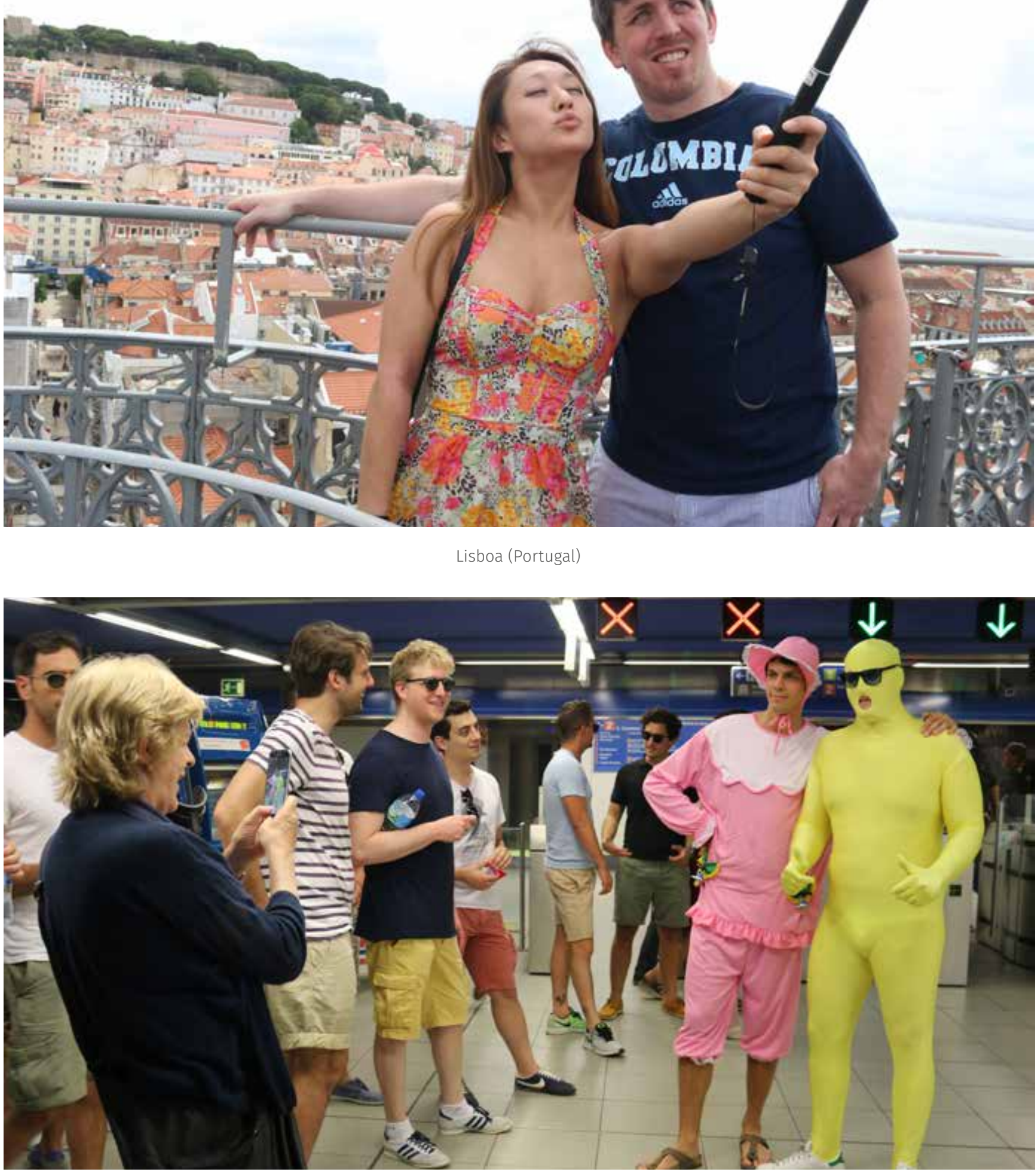


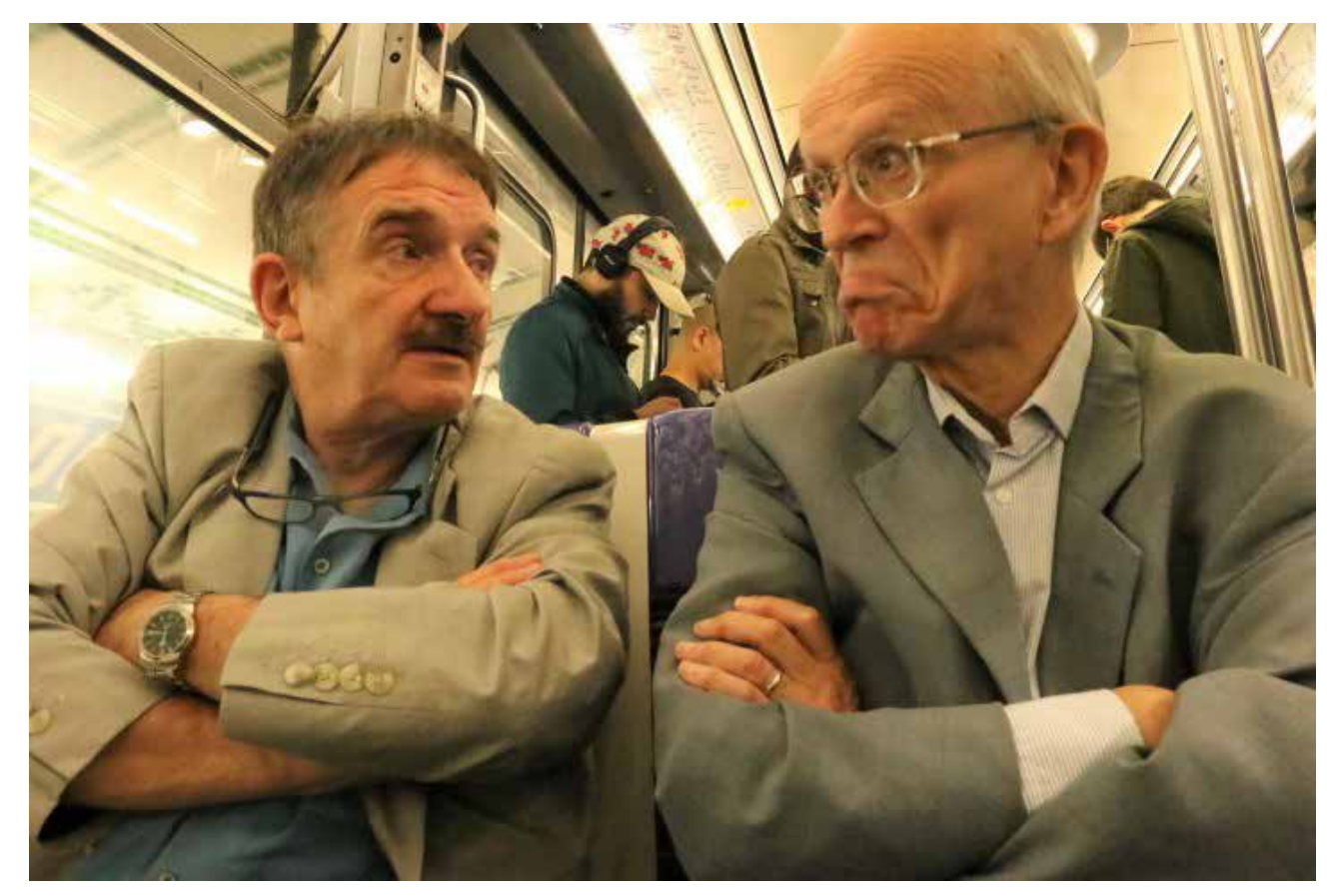

90

Comunicación

número 41

Julio - diciembre

2019

Paris (Francia)

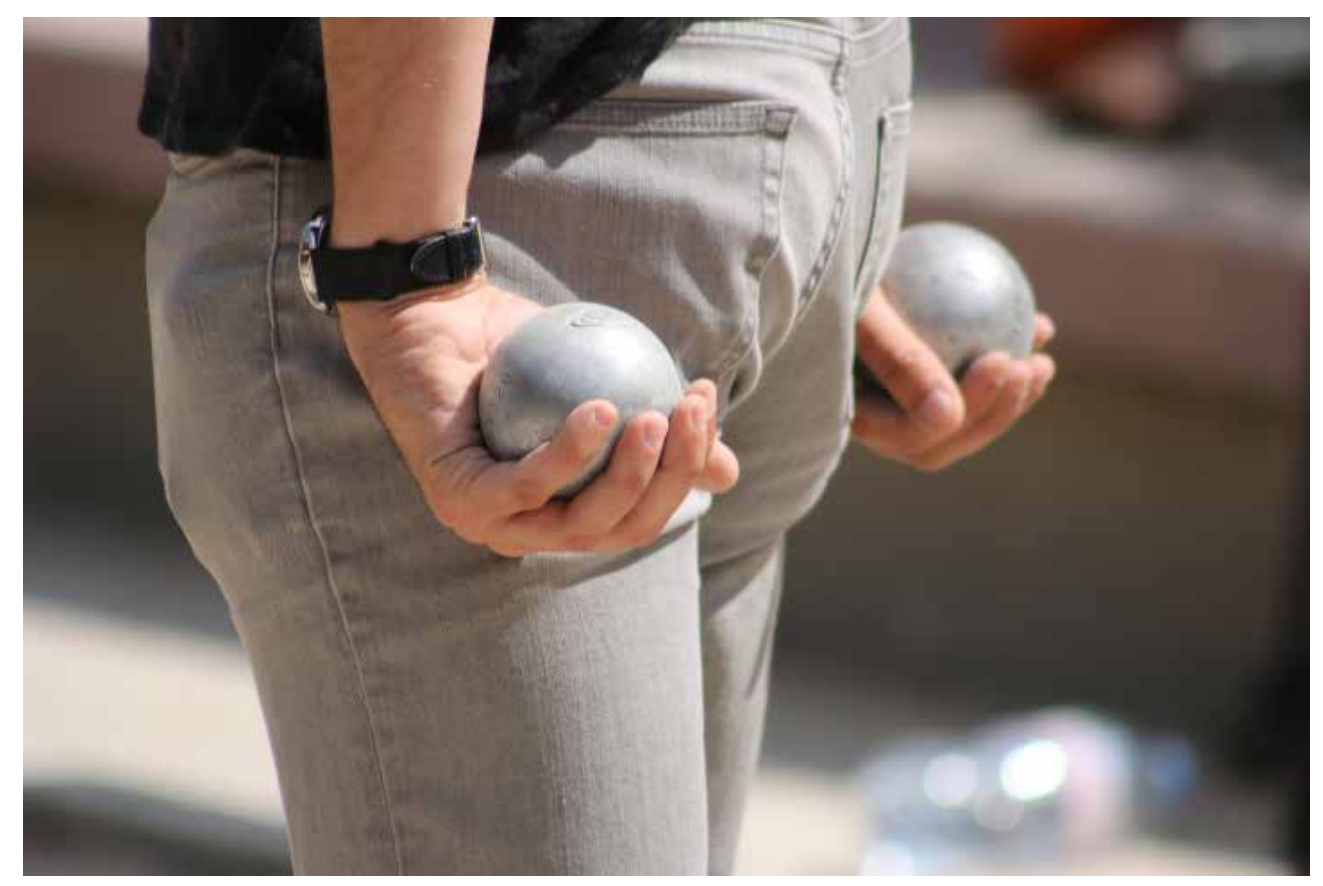

París (Francia) 


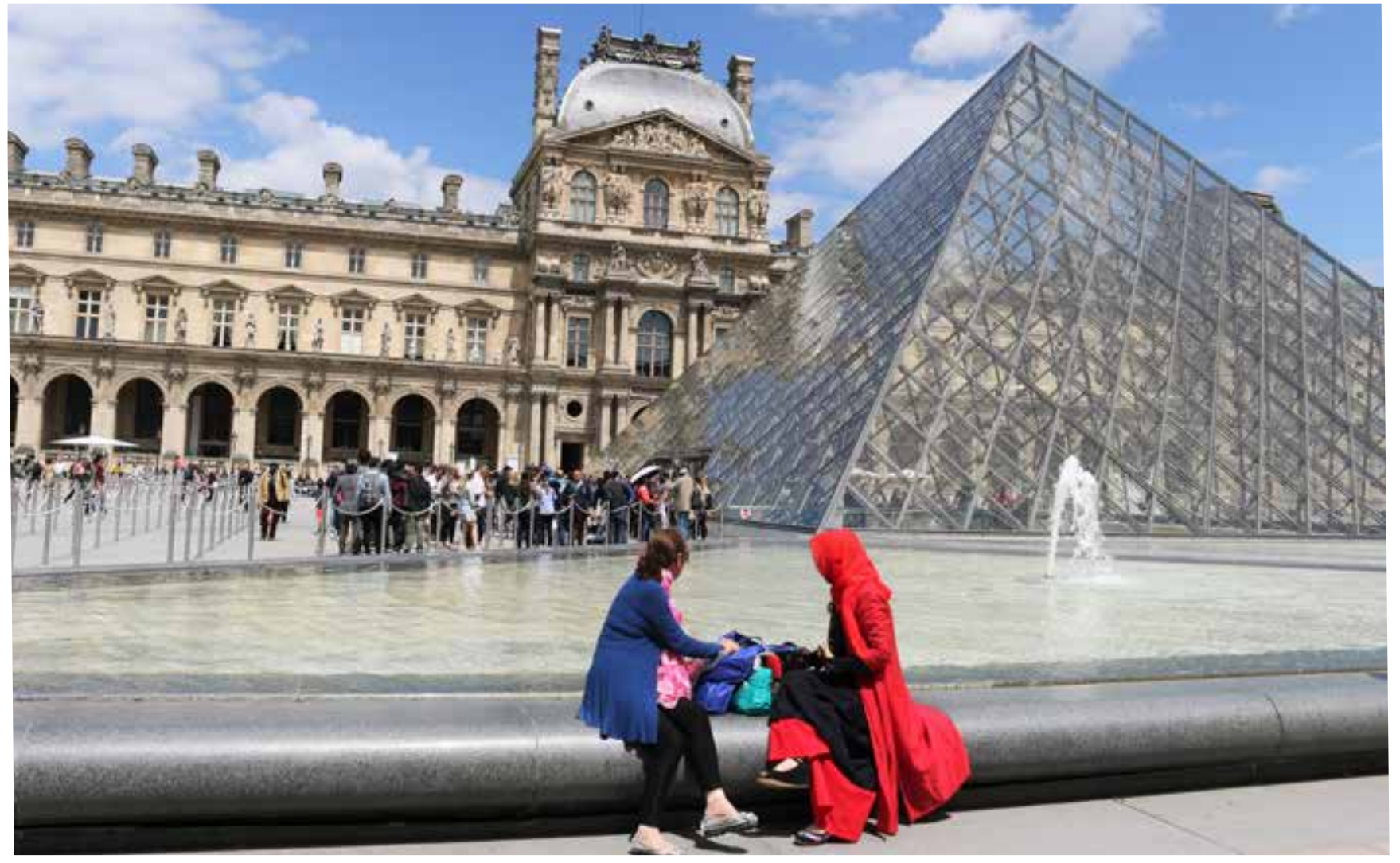

París (Francia)

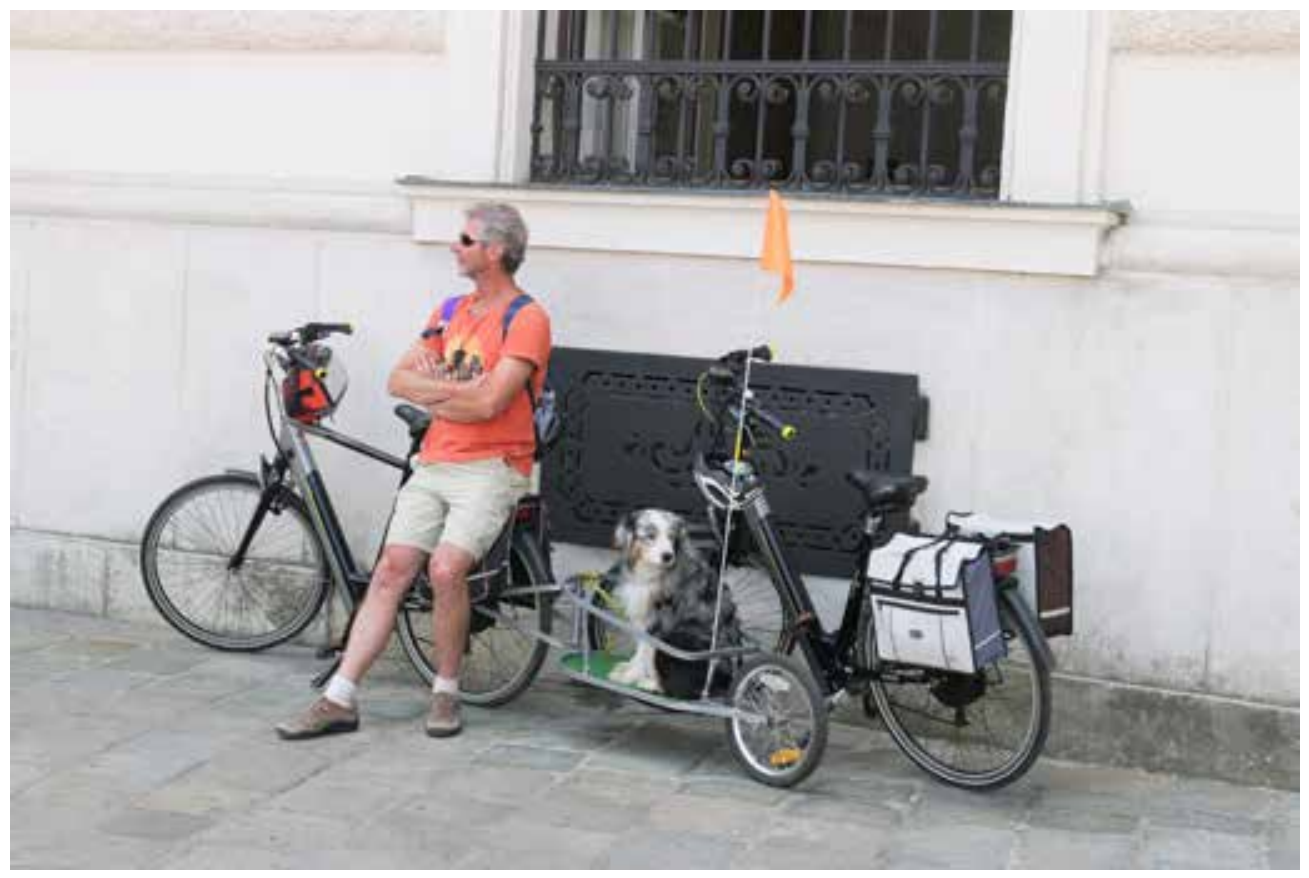

Viena (Austria) 


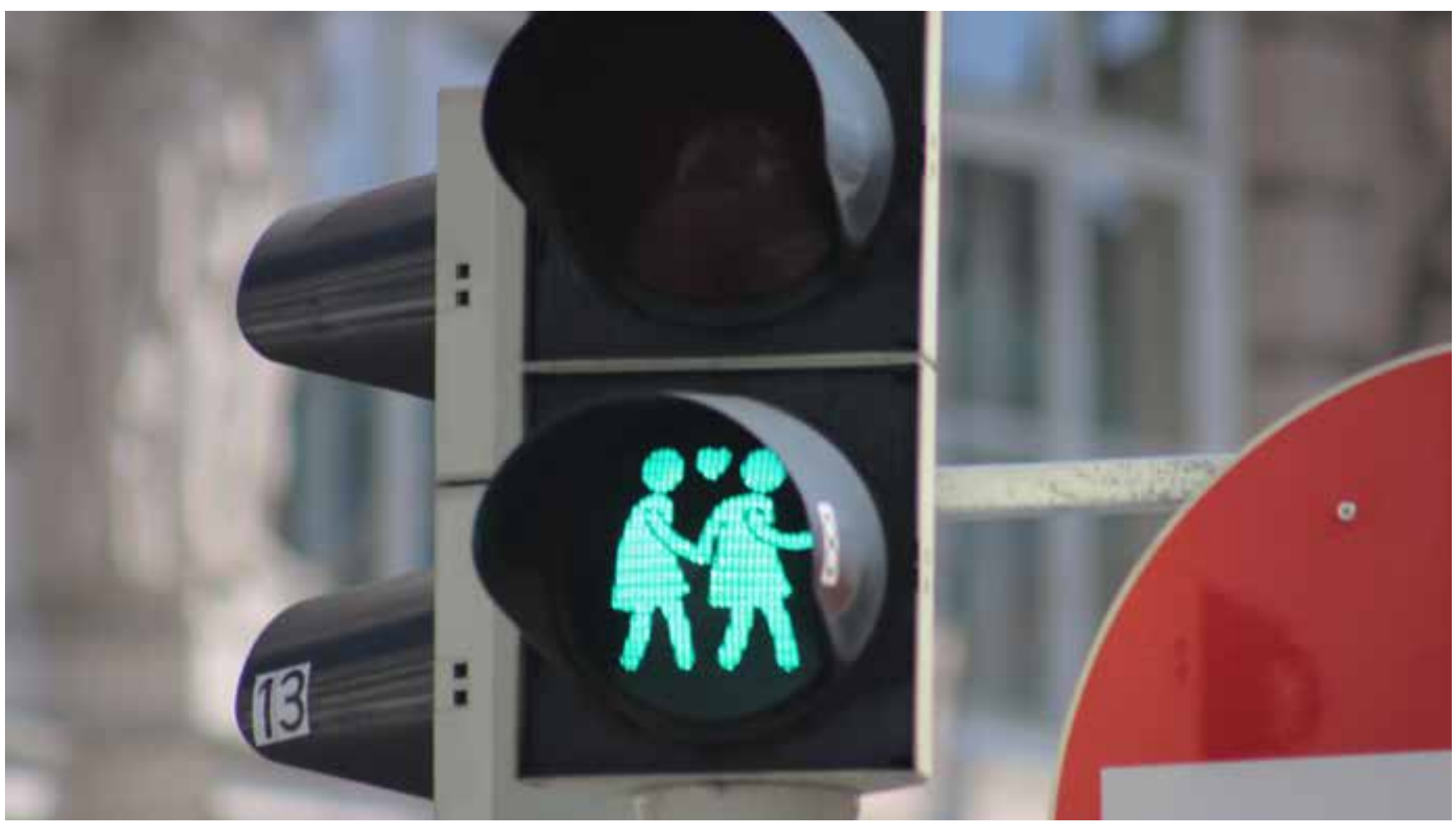

Viena (Austria)

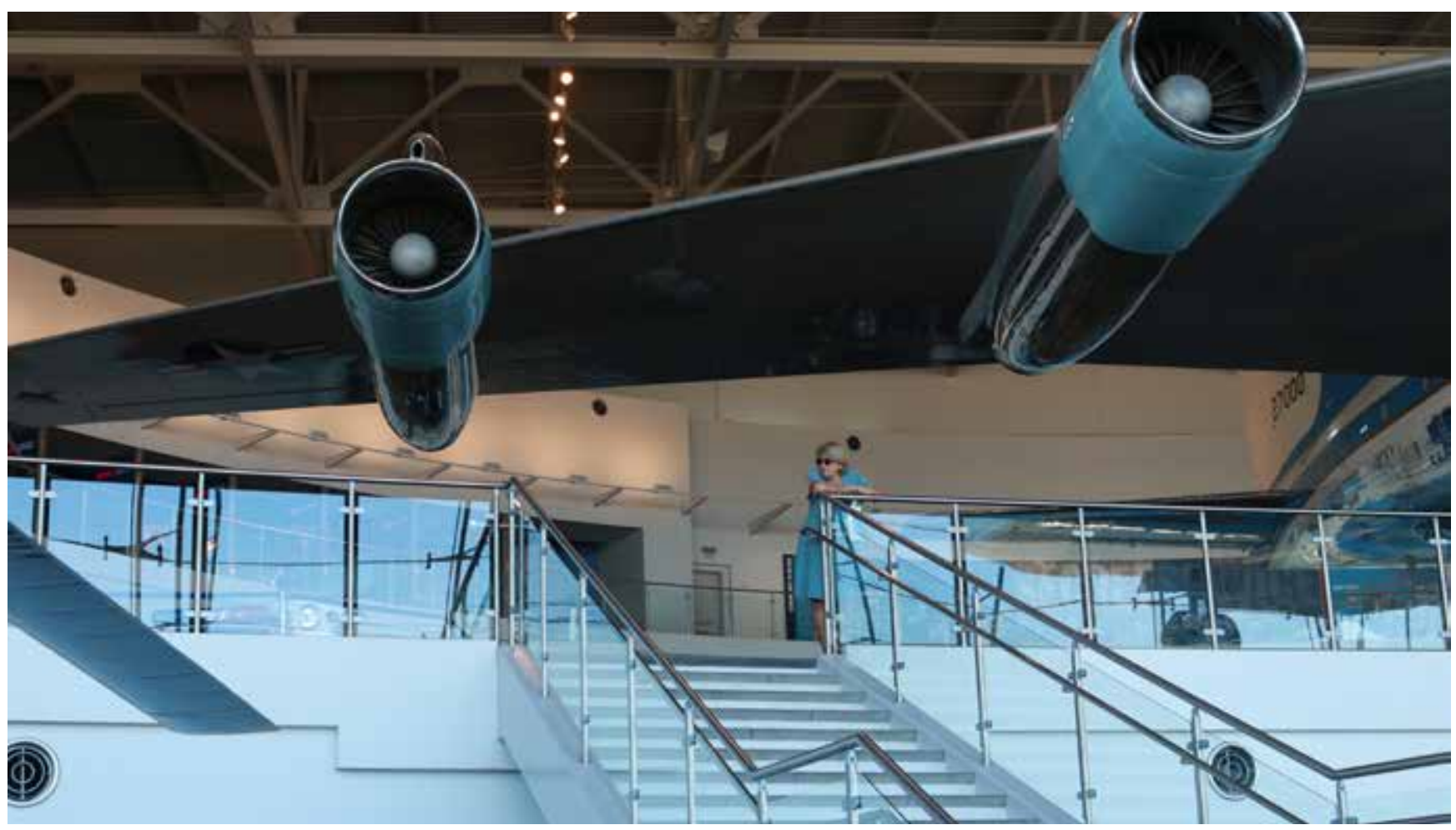

California (Estados Unidos) 


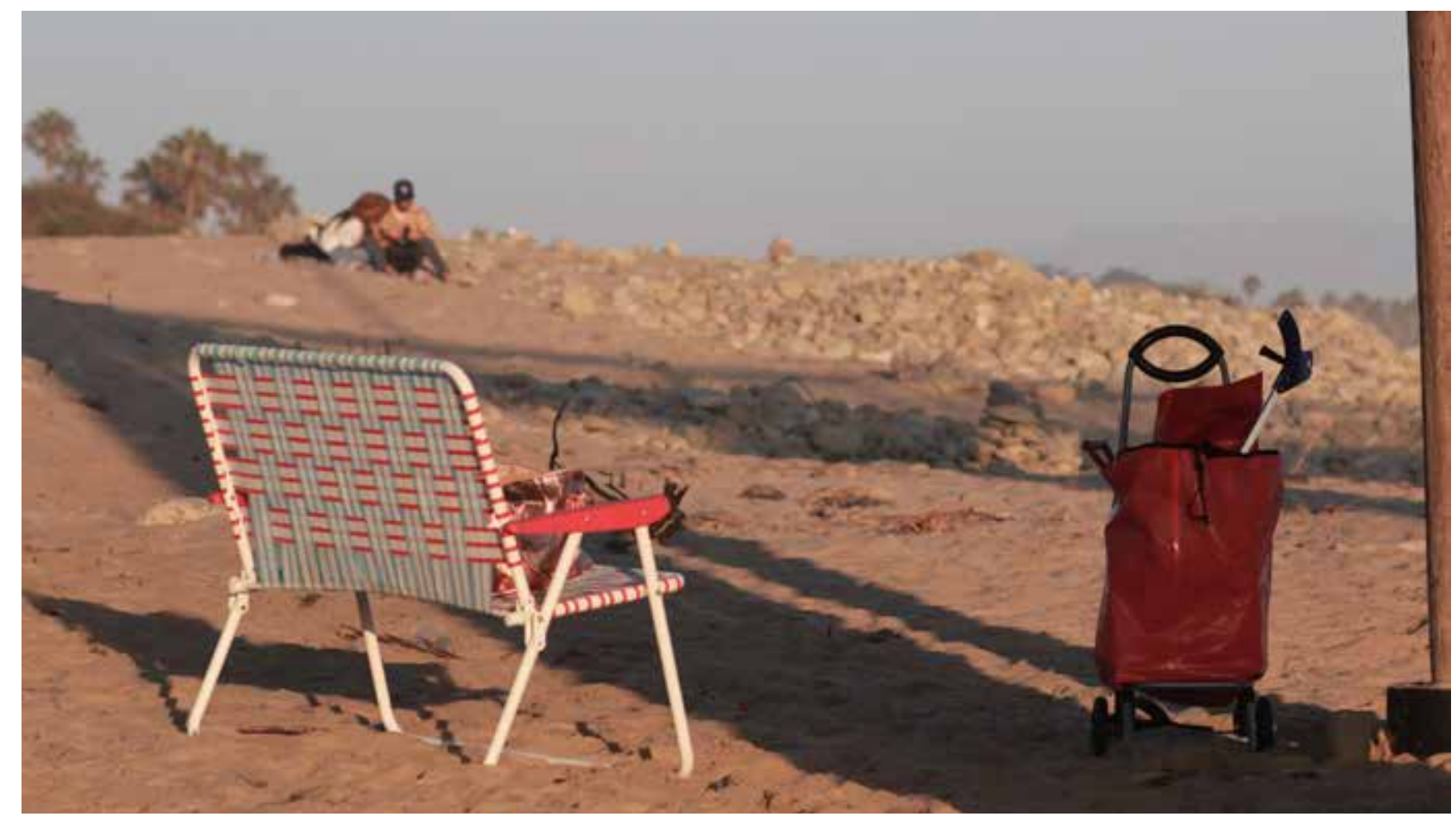

California (Estados Unidos)

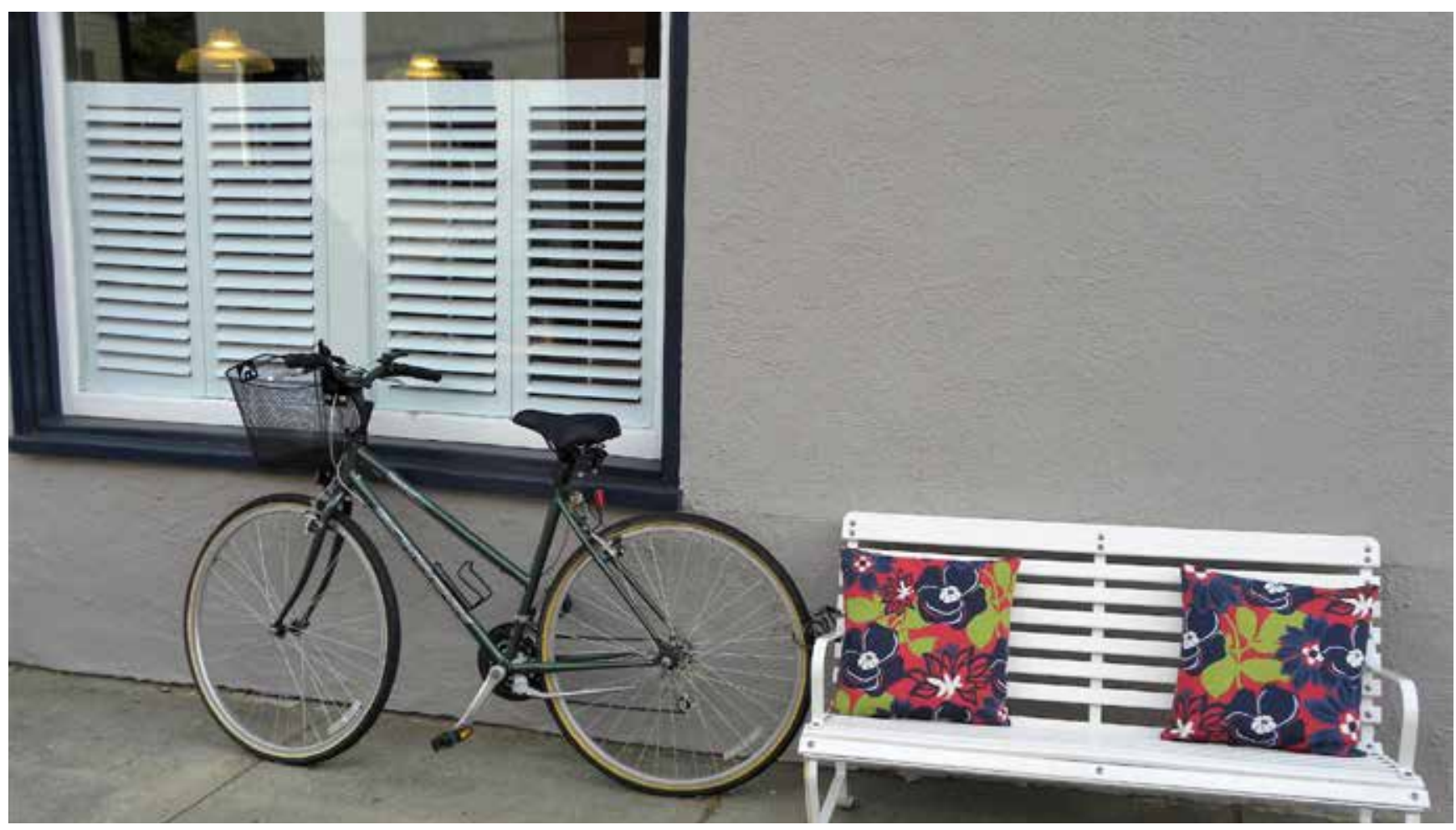




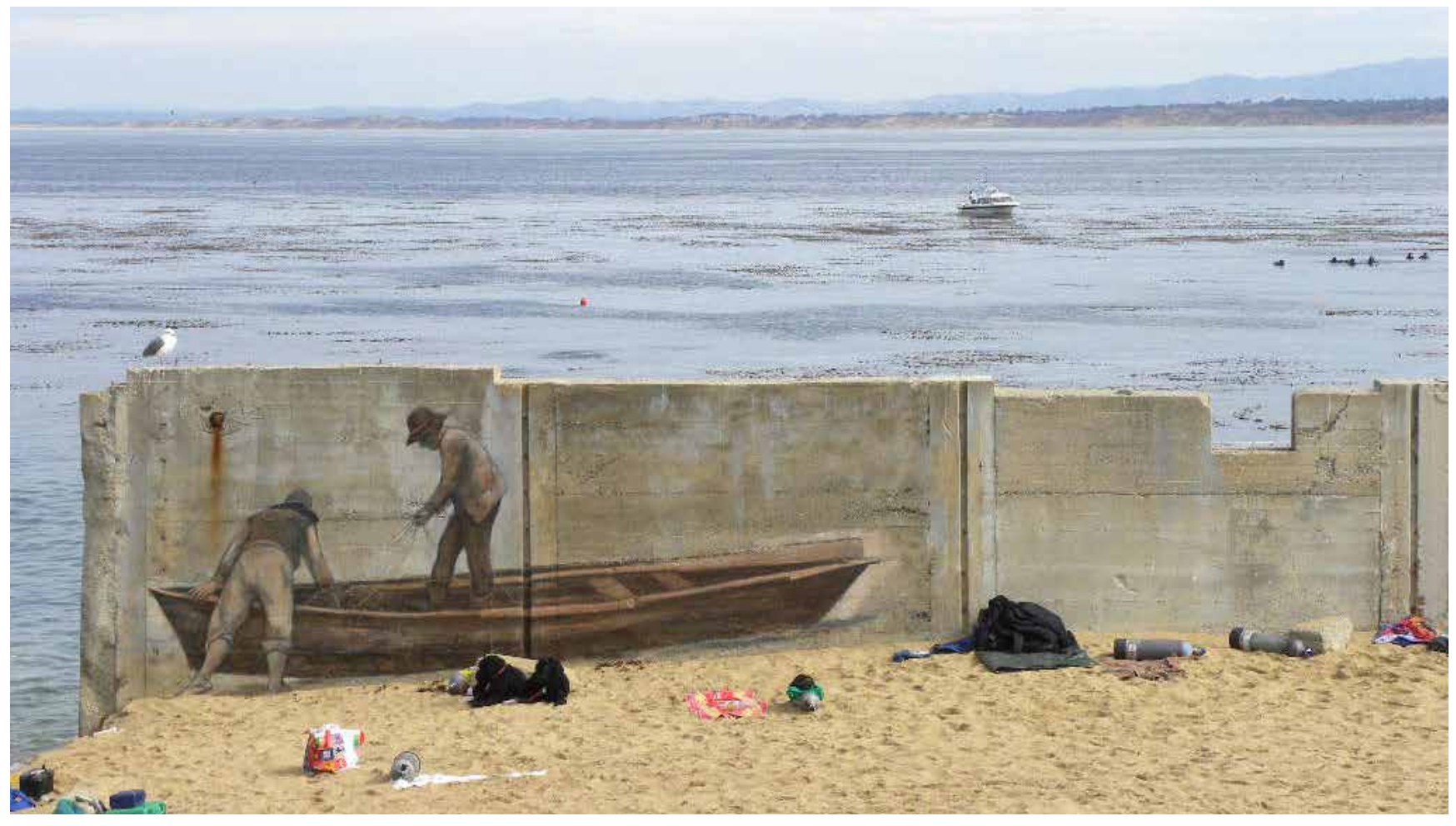

California (Estados Unidos)

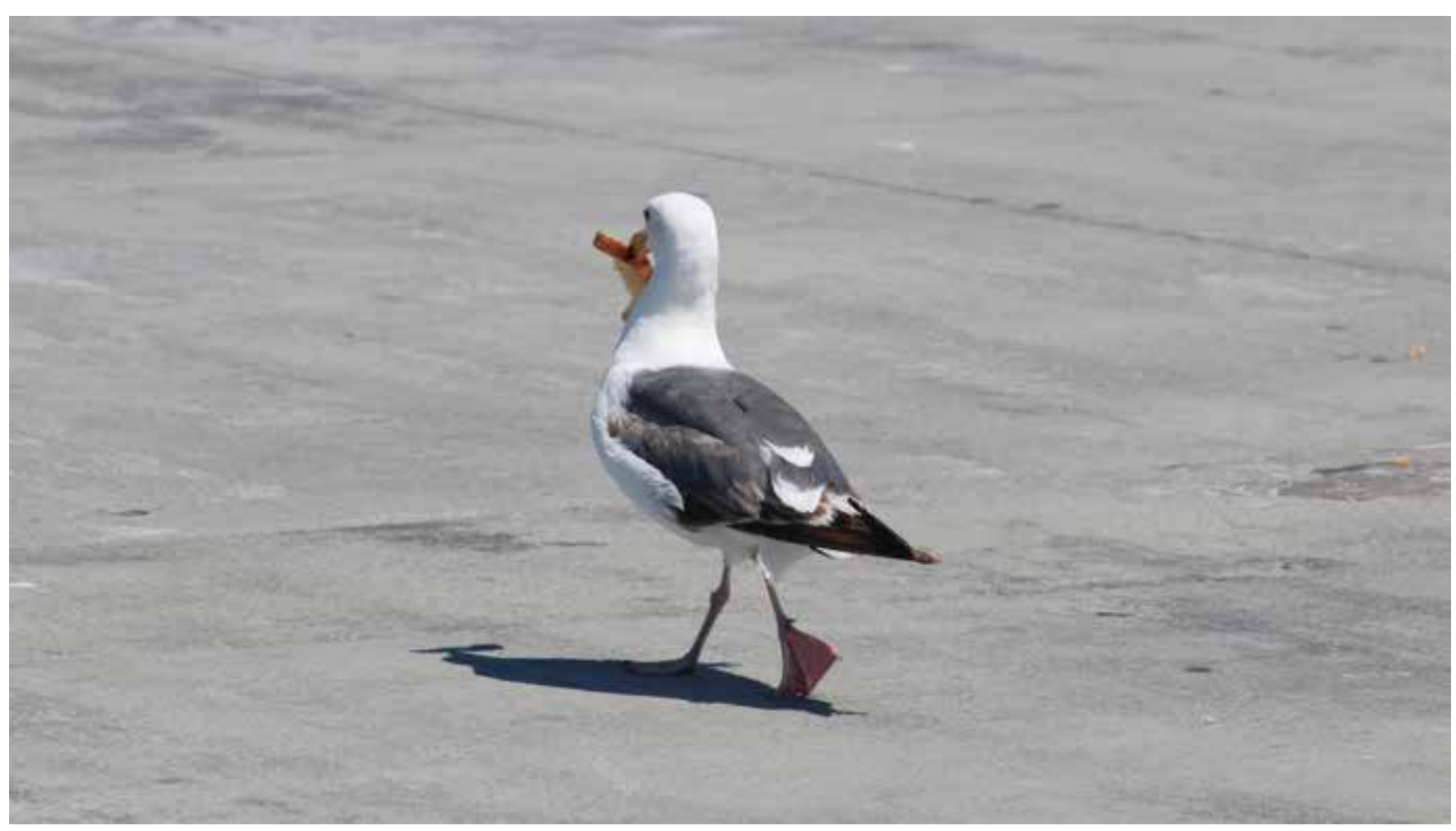

California (Estados Unidos) 


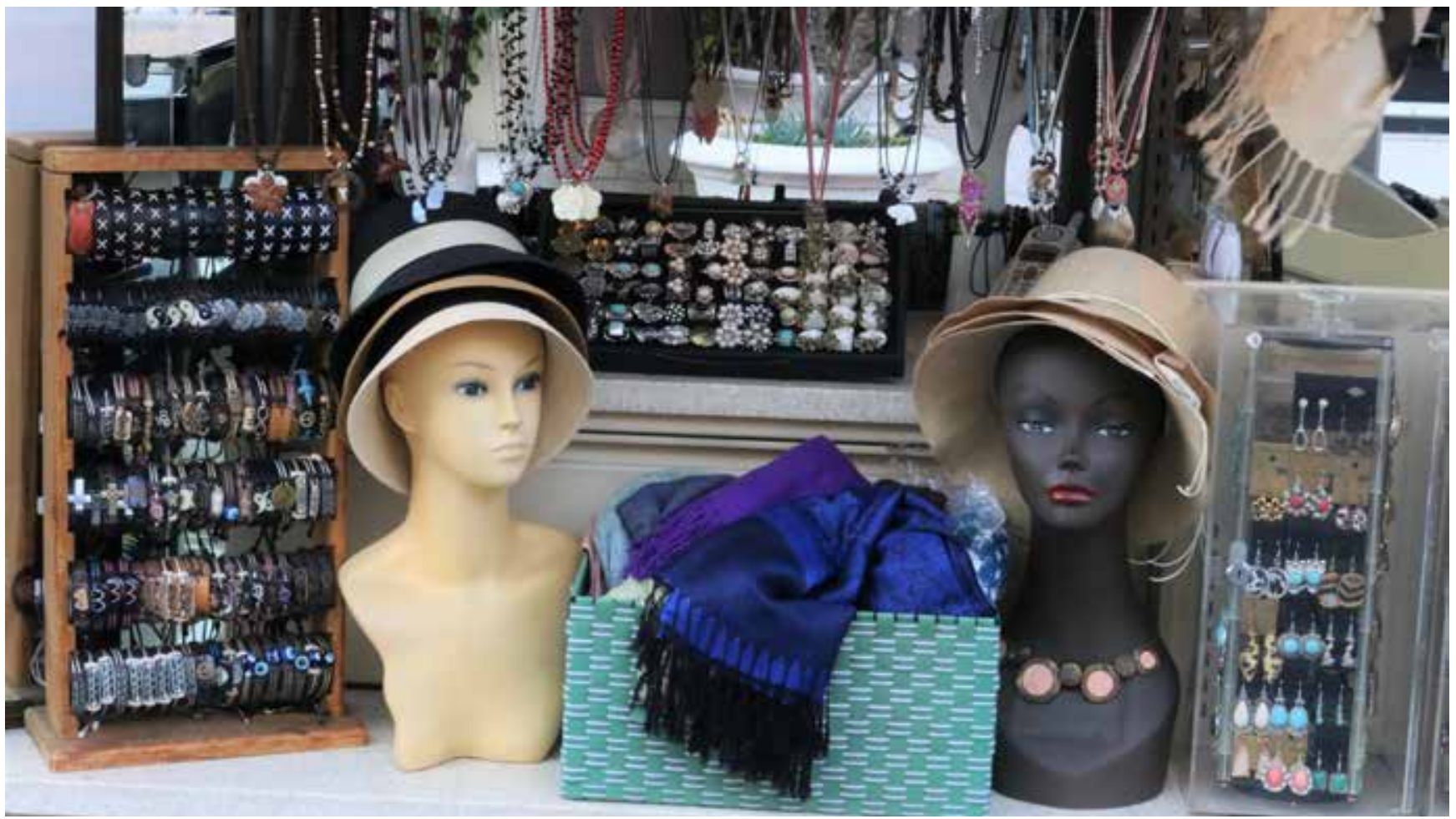

California (Estados Unidos)

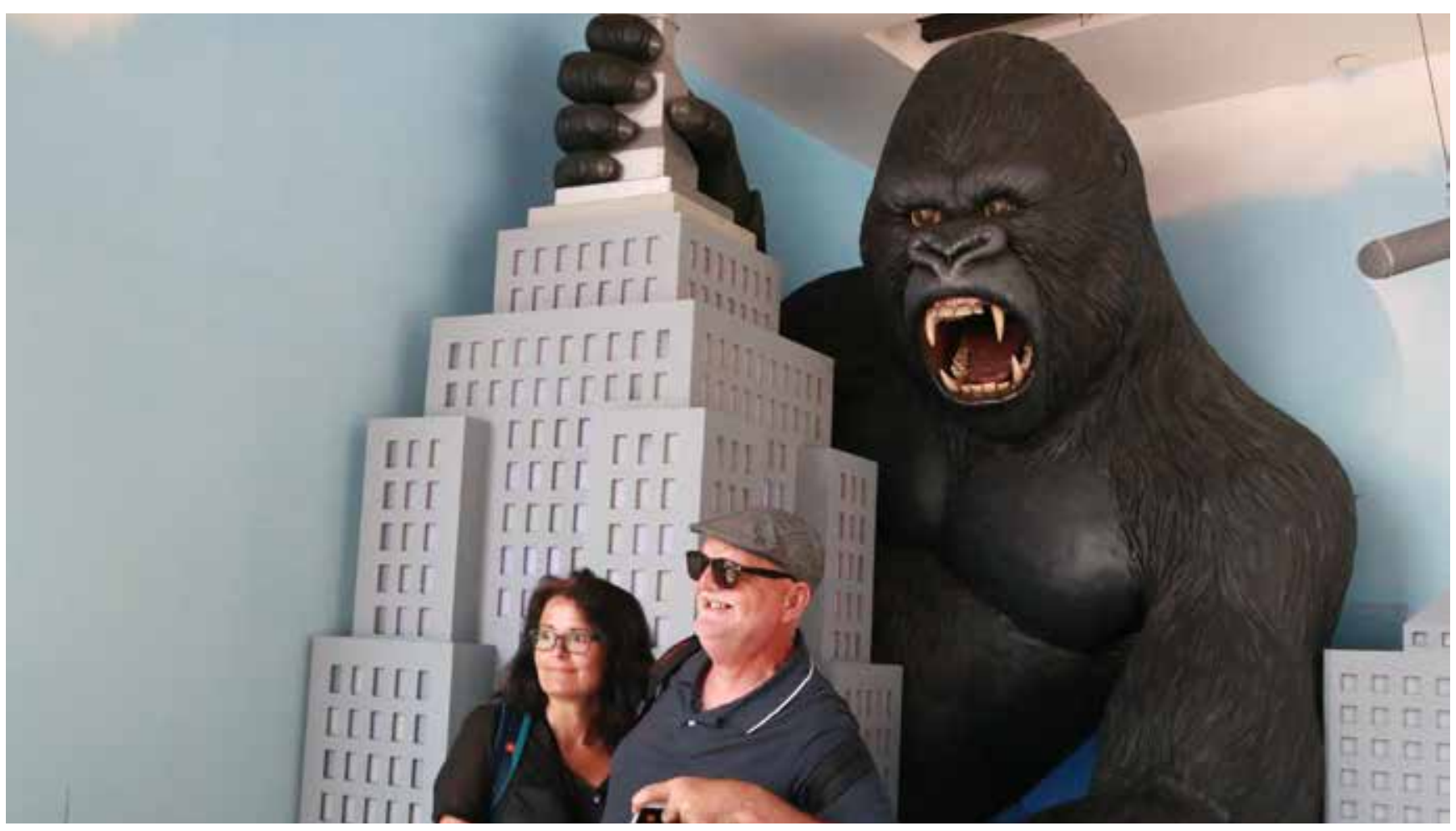




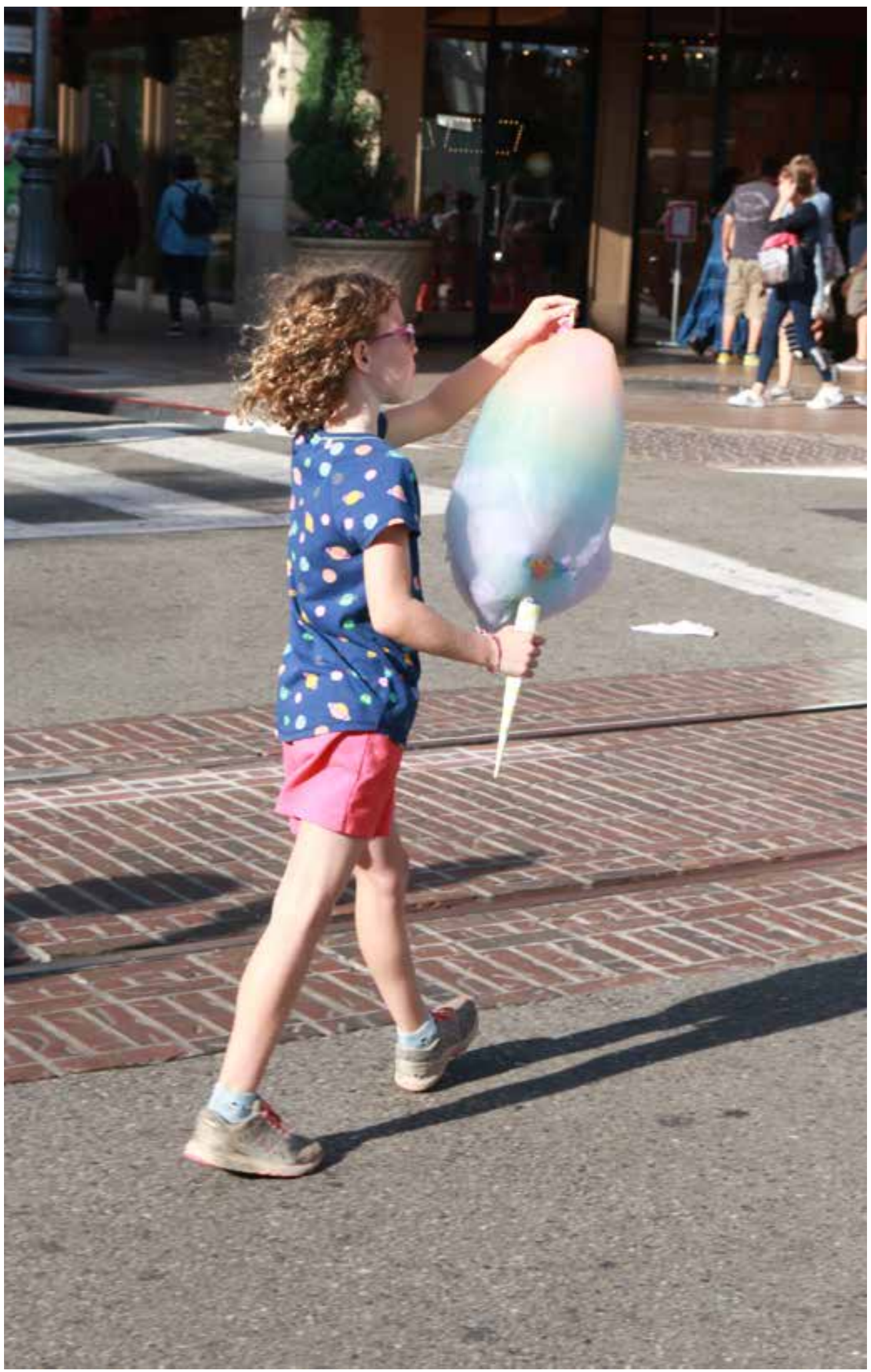

Los Ángeles (Estados Unidos) 

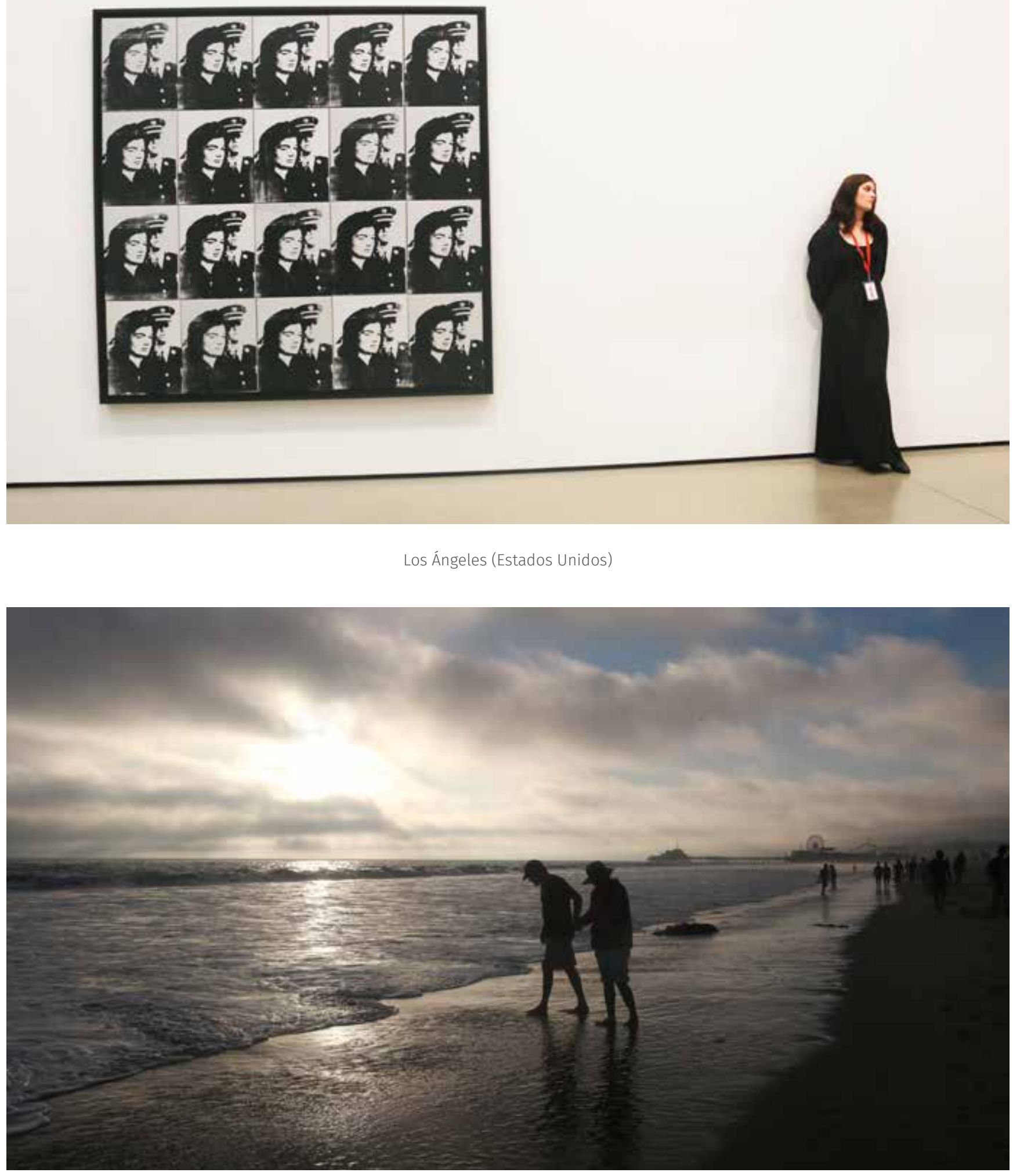
comunicación

número 41

Julio - diciembre

2019

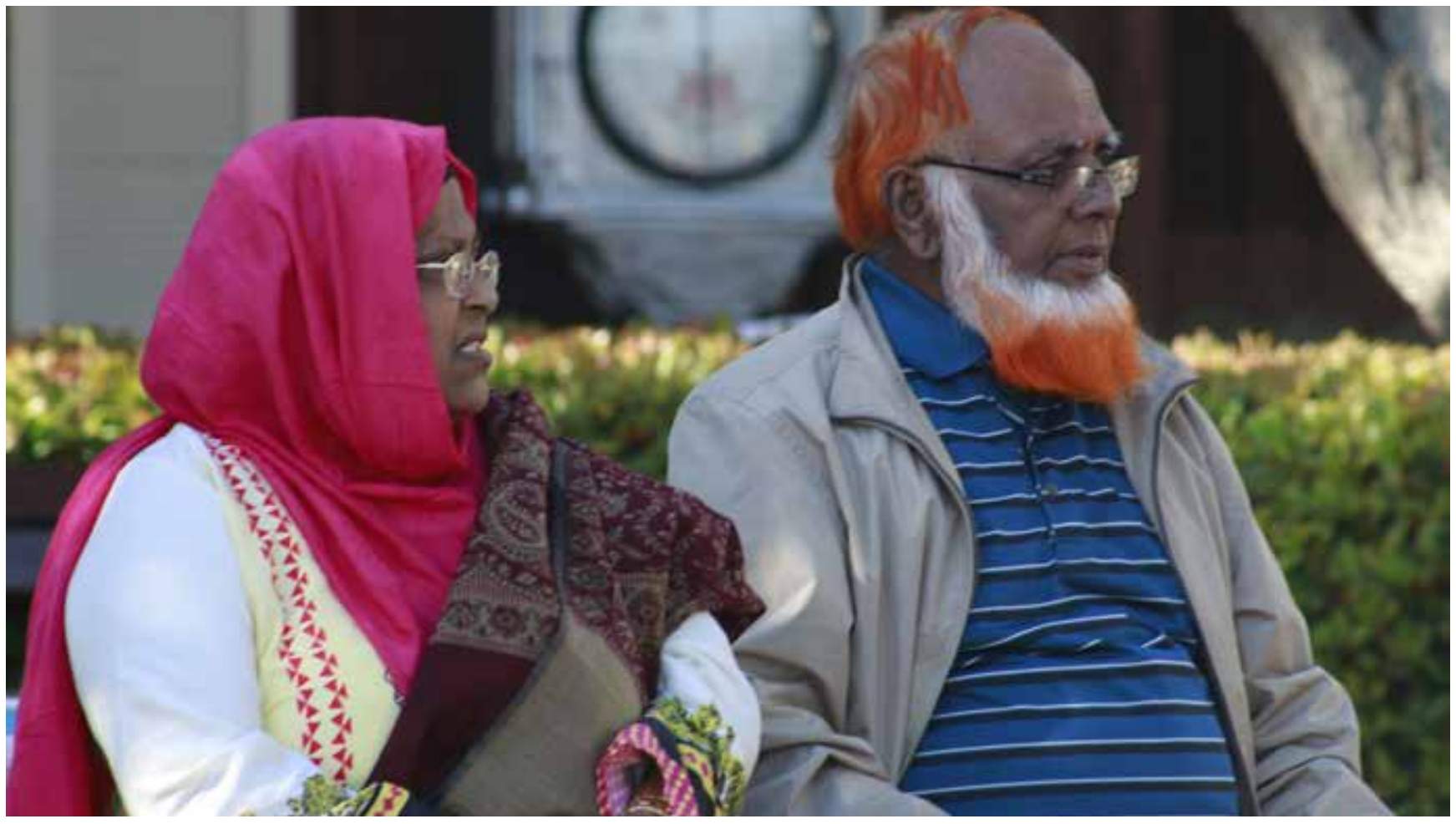

San Diego (Estados Unidos)

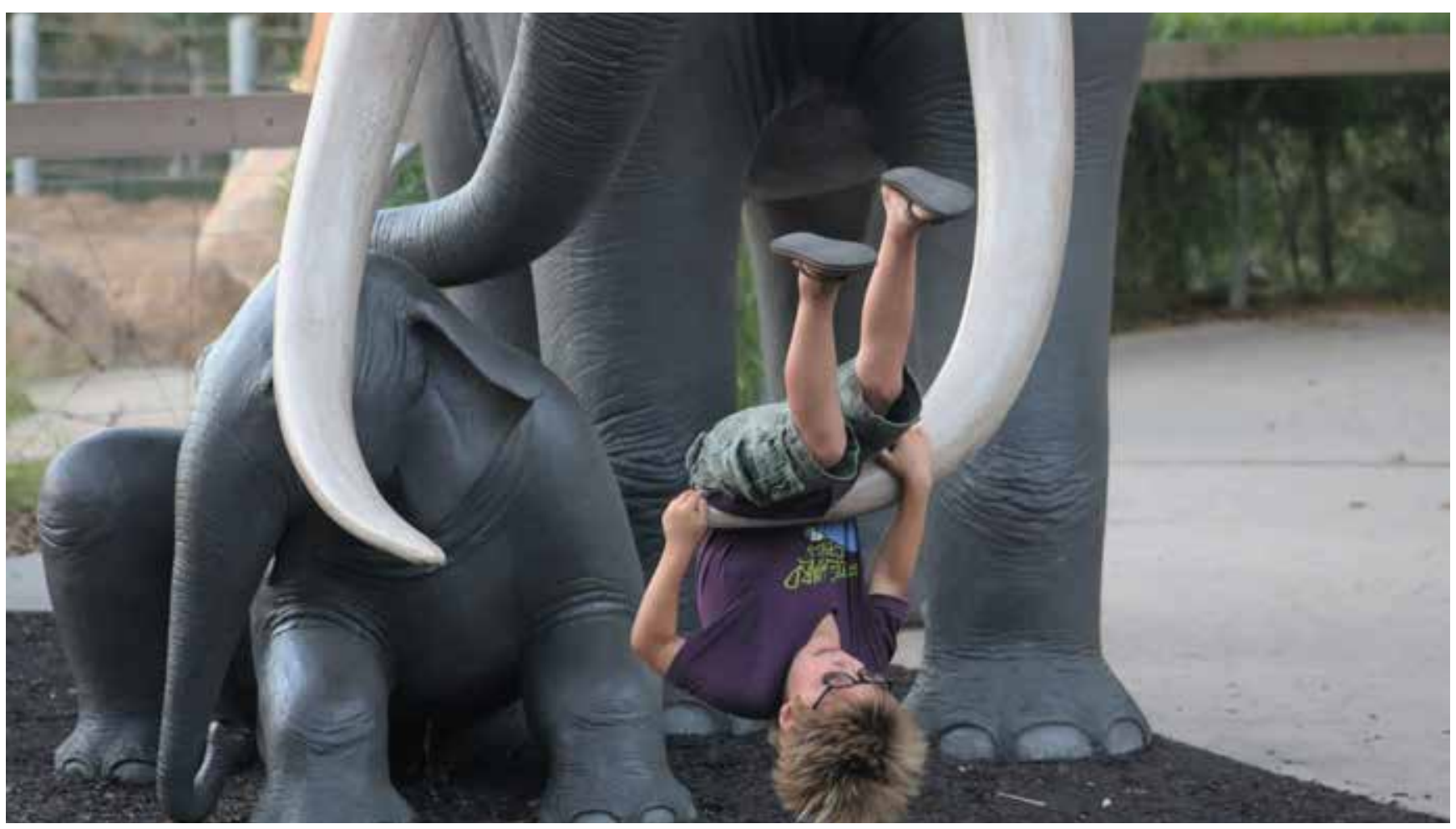

San Diego (Estados Unidos) 


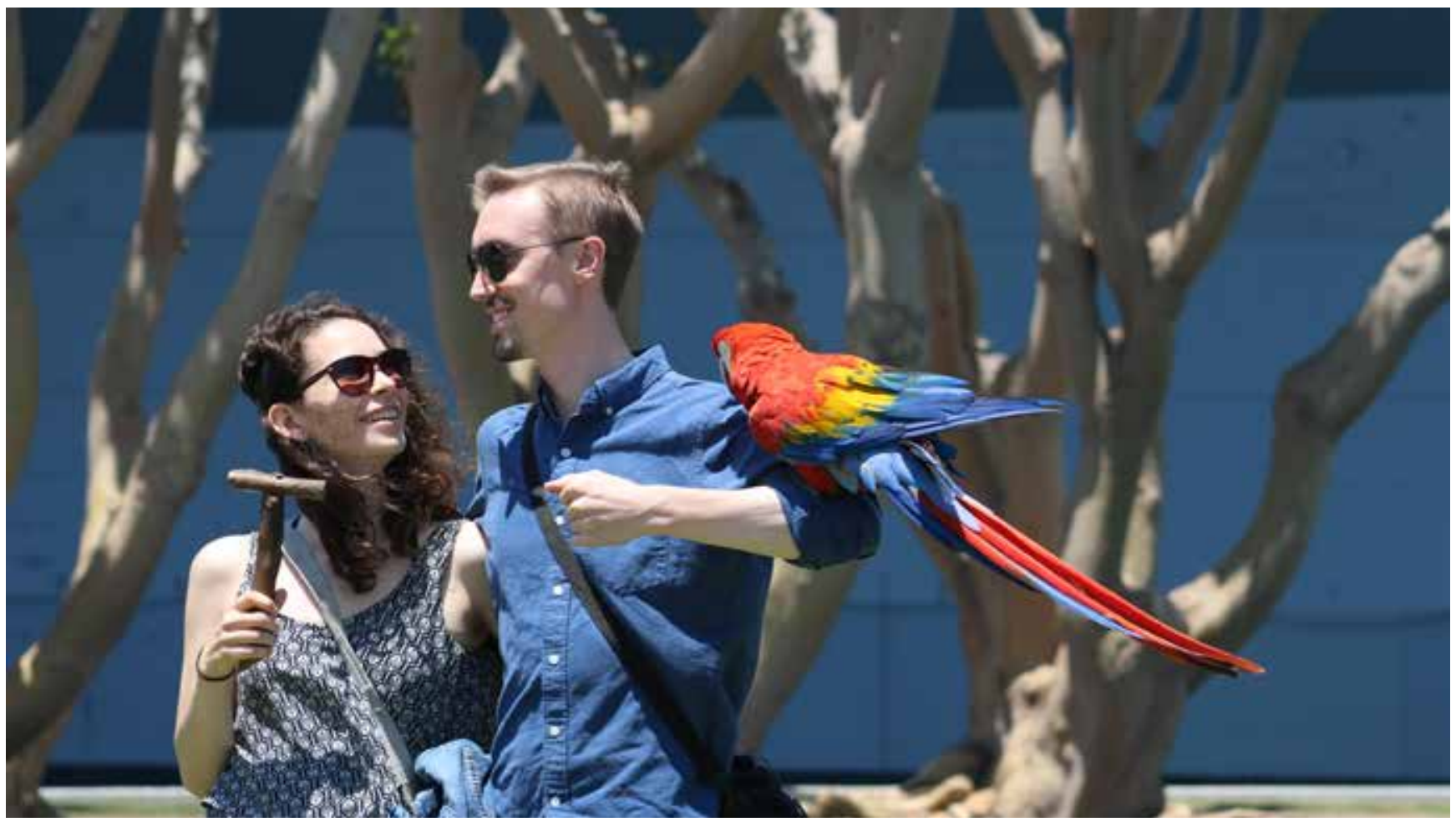

San Diego (Estados Unidos)

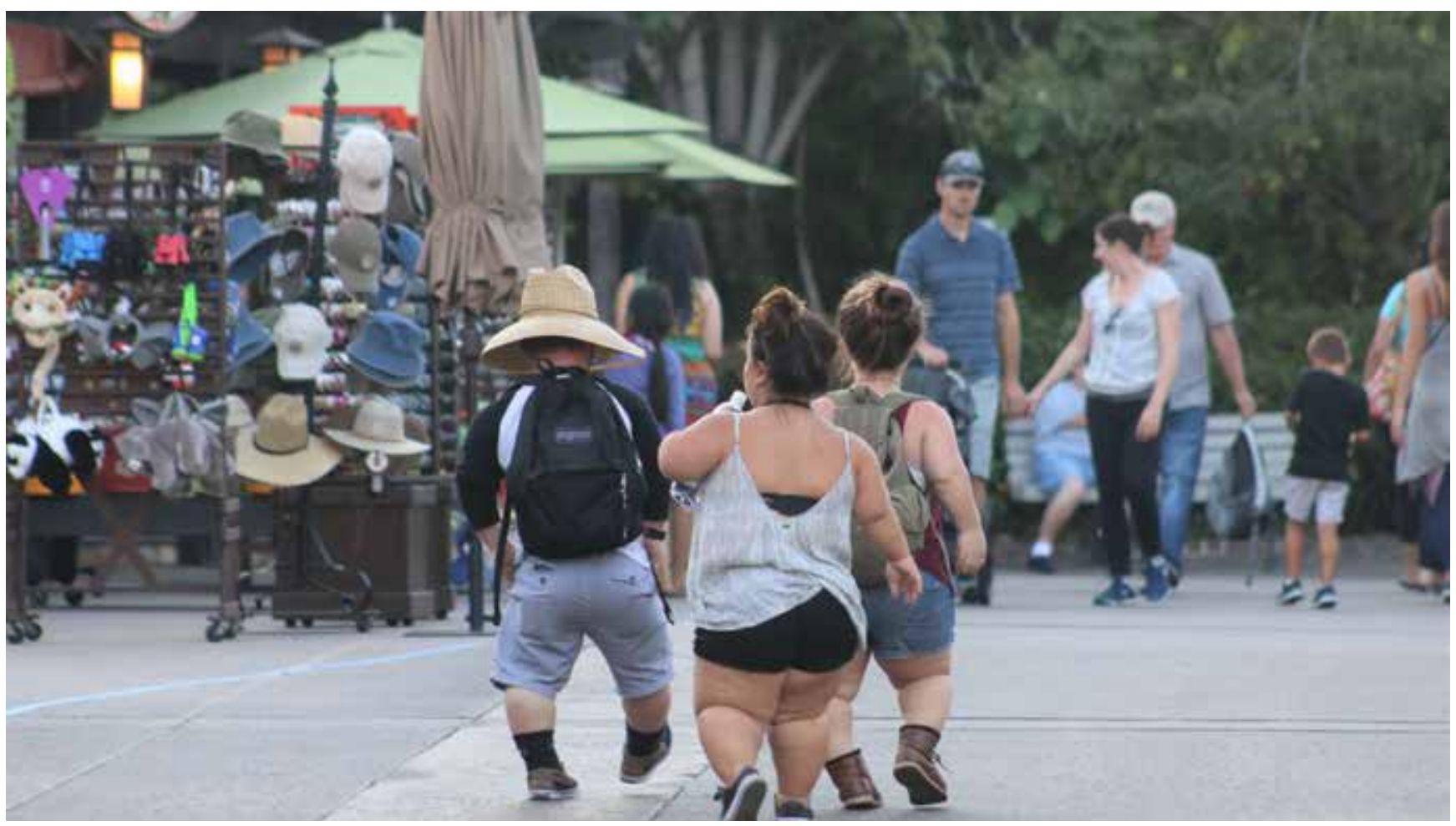




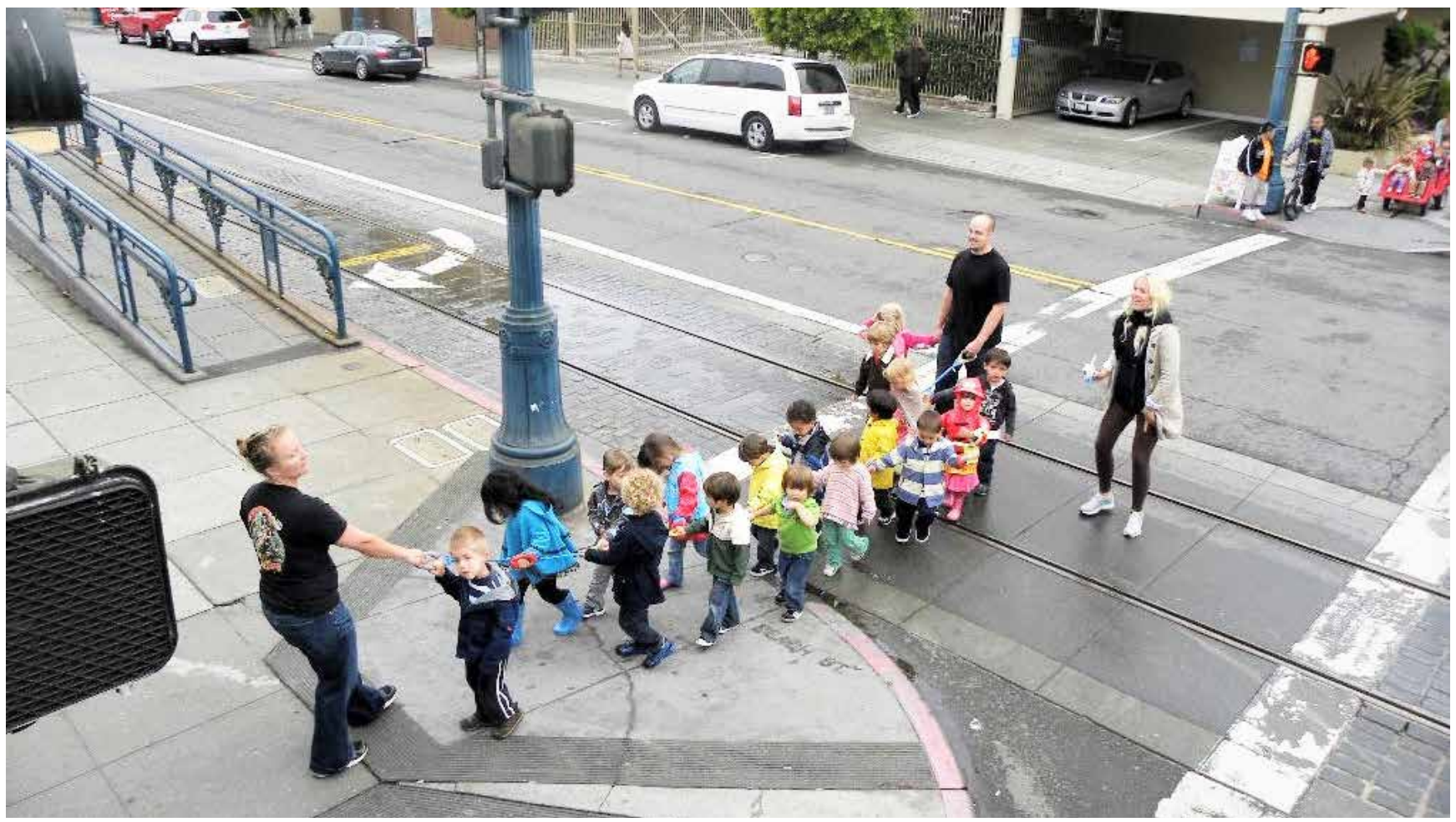

San Francisco (Estados Unidos)

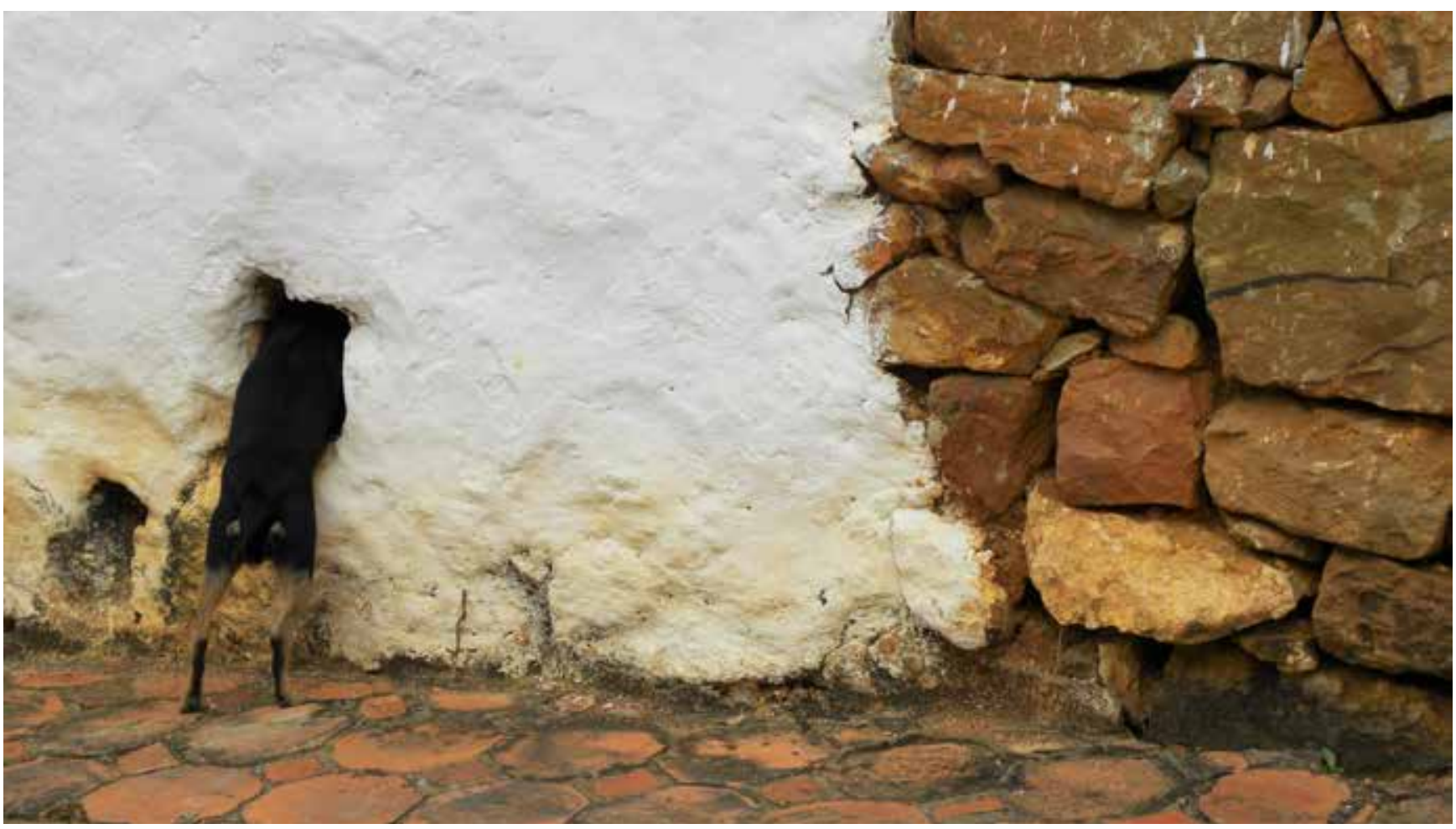




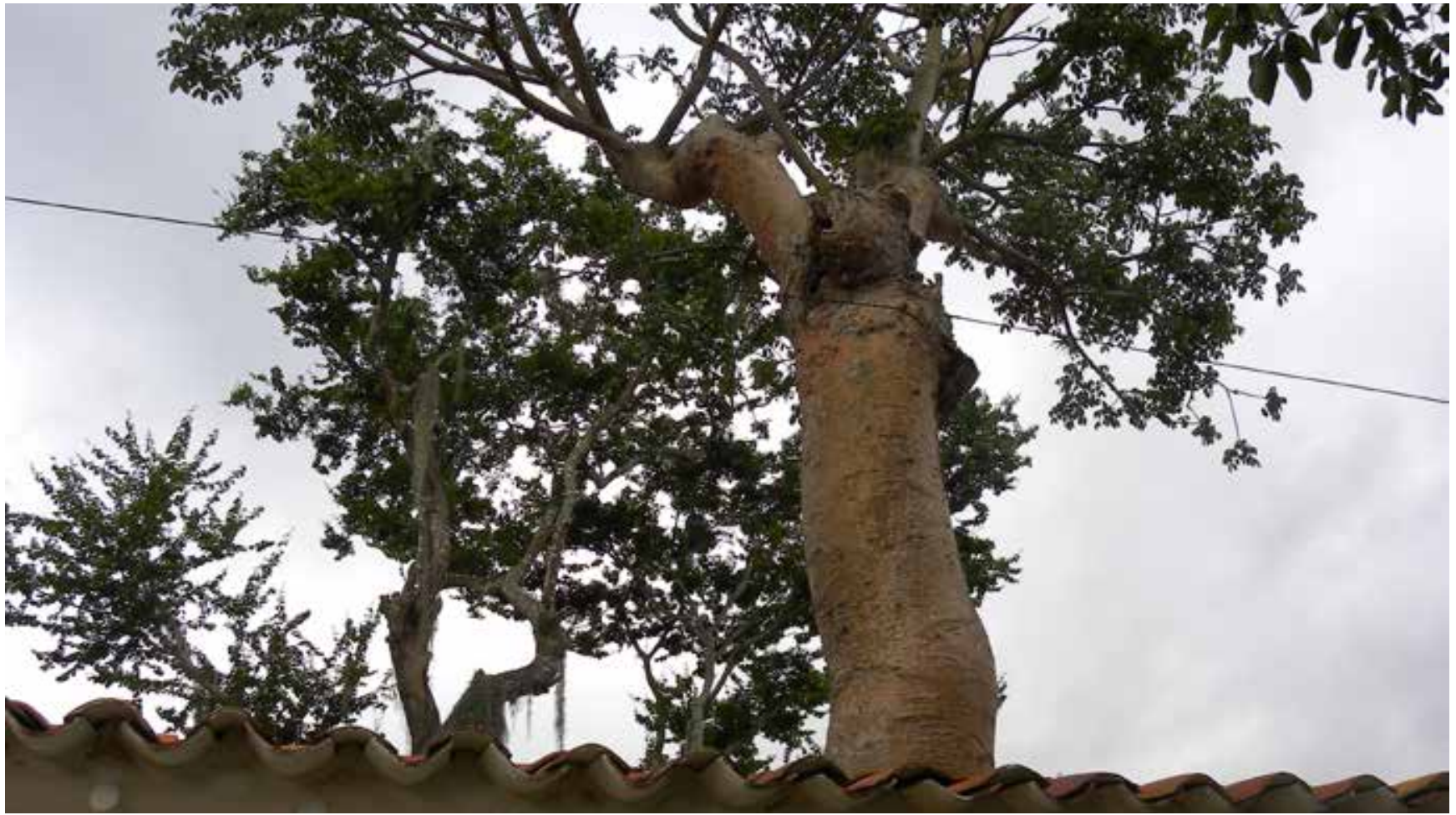

Barichara (Colombia)

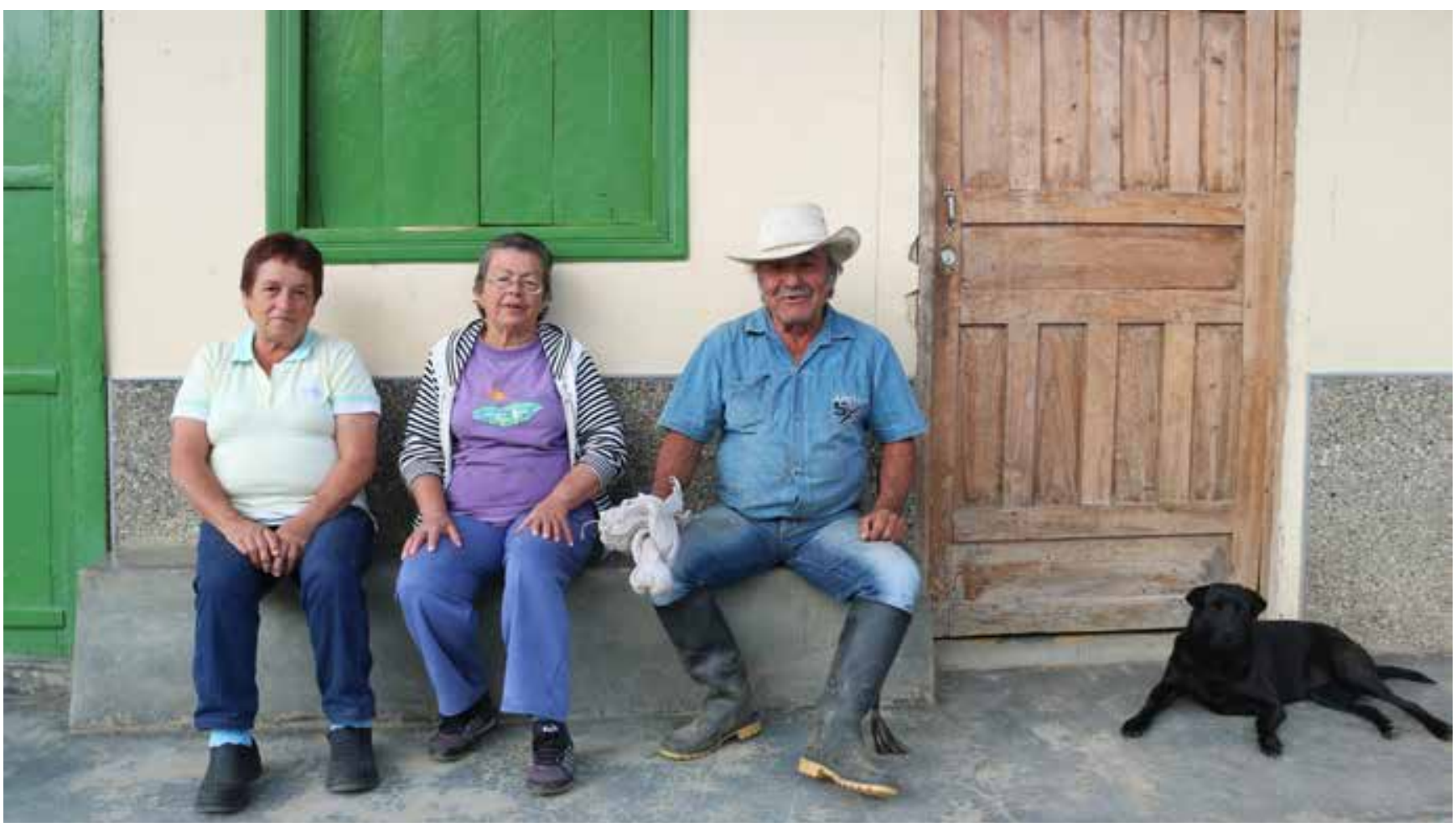


comunicación

número 41

Julio - diciembre

2019

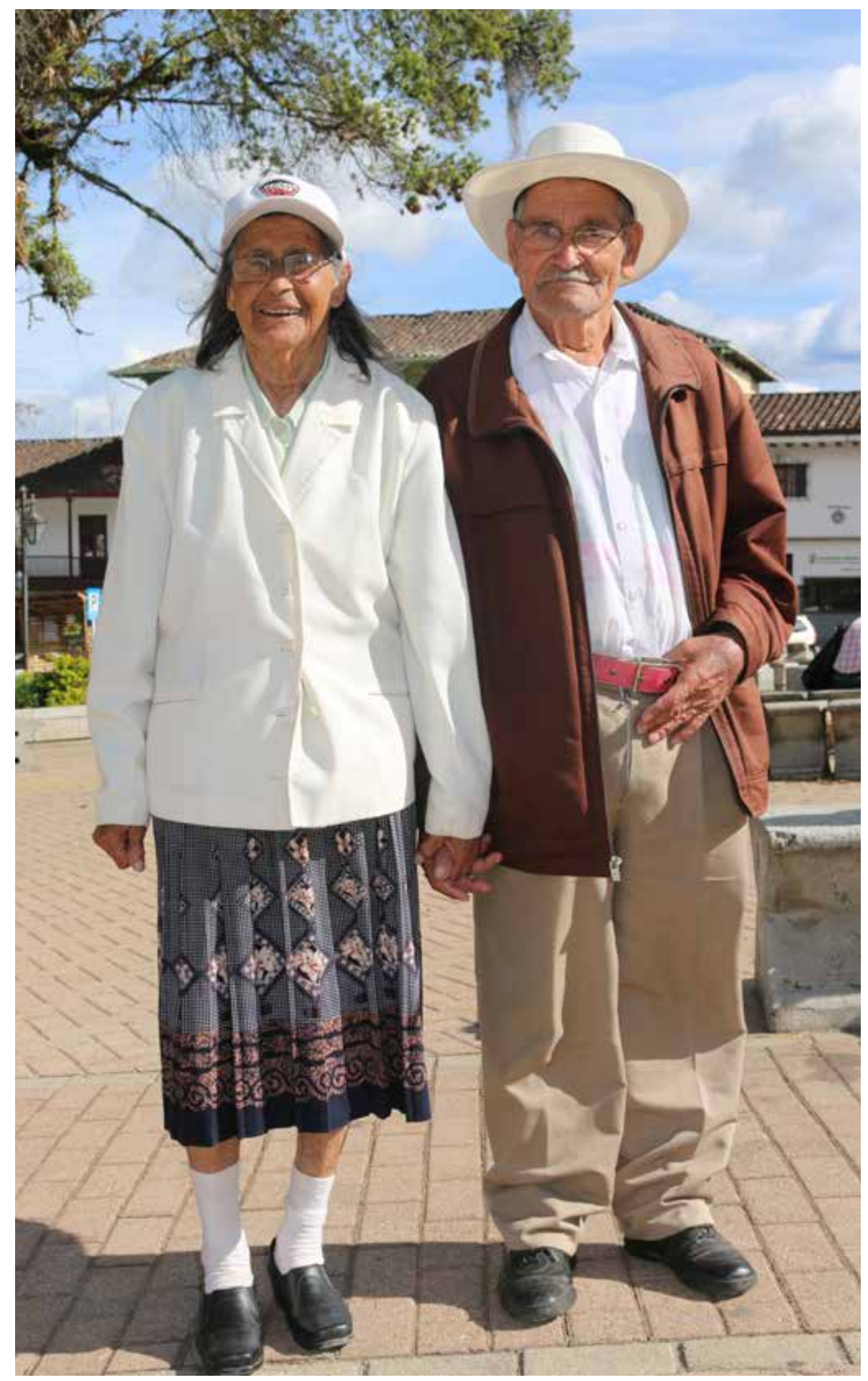


comunicación

número 41

Julio - diciembre

2019

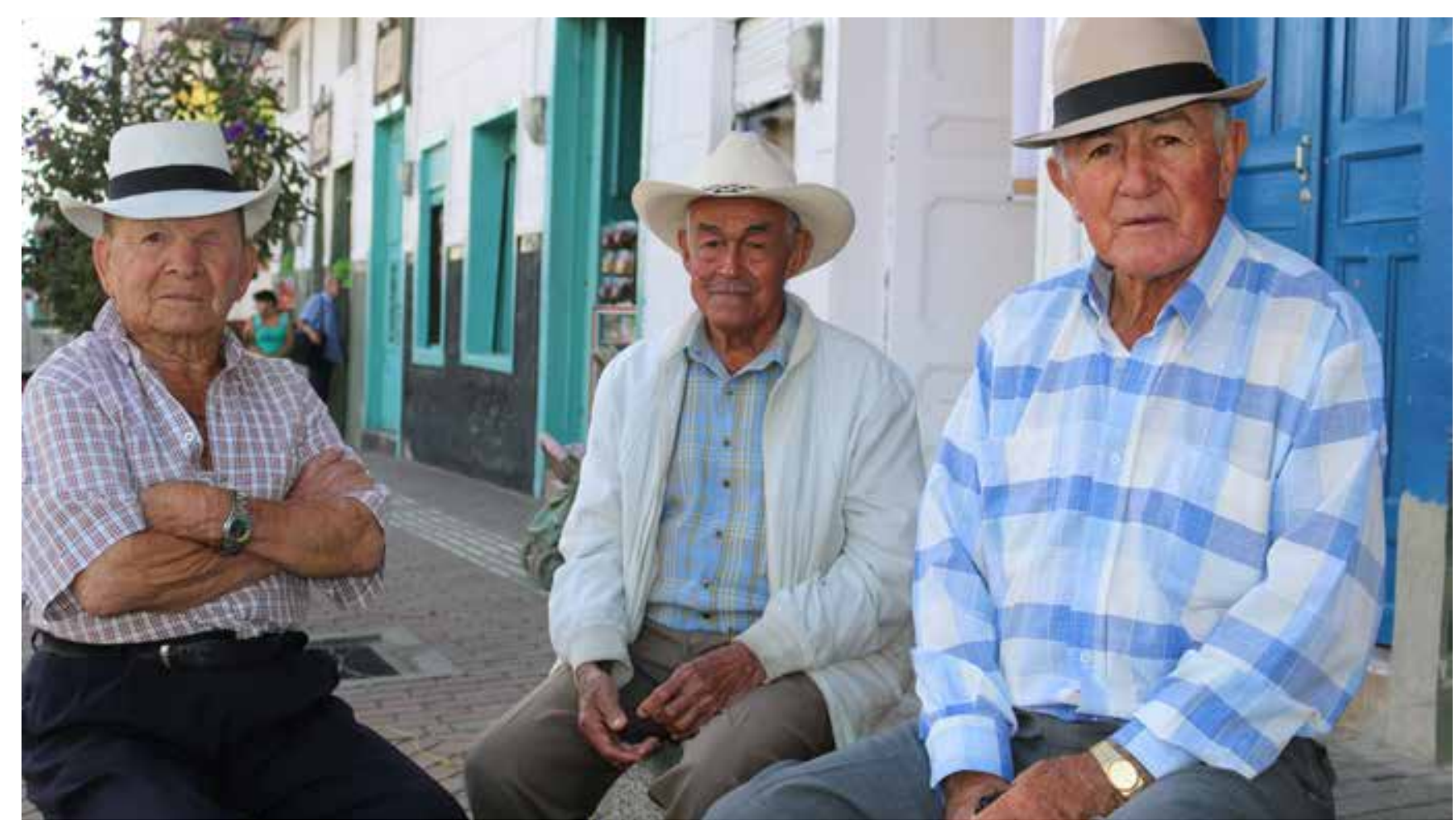

Sonsón (Colombia) 